\title{
Territorios urbanos a partir de las imágenes mediáticas: desfiles, carnavales, manifestaciones y revueltas en Bogotá*
}

\author{
URBAN TERRITORIES FROM THE MEDIA: PROCESSIONS, \\ CARNAVALES, PROTESTS AND RIOTS IN THE CITY OF BOGOTÁ \\ TERRITORIOS URBANOS A PARTIR DE IMAGENS DE MÍDIA: \\ DESFILES, CARNAVAIS, MANIFESTAÇÕES E TUMULTOS EM BOGOTÁ
}

\author{
Mauricio Durán Castro** \\ Cuadernos de Música, Artes Visuales y Artes Escénicas \\ / Volumen 9 - Número 1 / Enero - Junio de 2014 \\ / ISSN 1794-6670/ Bogotá, D.C., Colombia / pp. 95-138 \\ Fecha de recepción: 16 de septiembre de 2013 | Fecha de \\ aceptación: 10 de febrero de 2014. Encuentre este artículo \\ en http://cuadernosmusicayartes.javeriana.edu.co/ \\ doi:10.11144/Javeriana.MAVAE9-1.tupm
}

* Producto del Proyecto de investigación "La ciudad como matriz de territorio", del grupo "Pedagogía,

Tecnología y Sociedad en las Artes Visuales" del Departamento de Artes Visuales de la Facultad de Artes de la Pontificia Universidad Javeriana.

** Profesor, Departamento de Artes Visuales, Facultad de Artes, Pontificia Universidad Javeriana. 


\section{Resumen}

Concebimos hacer territorio como una forma de expresión colectiva, y hacerlo en la modernidad implica dos nuevos aspectos: el contexto urbano y el uso de modernos medios de comunicación. Hace un siglo que se registran en imágenes distintas procesiones, desfiles, carnavales, manifestaciones y revueltas en el espacio público, convirtiéndose en documentos o sirviendo como herramienta para realizar tales eventos. La disposición de la población al congregarse y participar en estos, expresa formas de apropiación de lo público y construcción de territorios comunes; pero también el uso de los medios posibilita nuevas formas expresivas de territorios. El espacio histórico y cultural más importante de Bogotá -la carrera séptima convergiendo en la plaza de Bolivar-, ha sido escenario de este tipo de eventos, "puestos en escena" y registrados en imágenes, desde el cine mudo hasta el video por internet. Estudiaremos como el documental, el cine de ficción o el video en internet, promueven discursos oficiales hegemónicos o expresan diferentes necesidades culturales, constituyendo diversos sujetos (pueblo, multitud o masa), que participan de la construcción de nuevas formas de territorios.

Palabras clave: territorios; territorialización y desterritorialización; ciudad; espacio urbano; pueblo, multitudes; masas; cultura popular; desfiles; carnavales; manifestaciones; imágenes mediáticas; cine

Palabras clave descriptores: espacio urbano; aspectos sociales; cultura popular; carnavales

\section{Abstract}

In the contemporary world, the issue of forming territory is decisively marked by two aspects: the urban environment and the use of new media and communications technologies.

In the city of Bogotá, in its most significant public space, the one with the most relevant historic and cultural significance -the Avenue 7th or Carrera Séptima and the Plaza de Bolivar-, we can identify public events such as processions, parades, carnivals, demonstrations and riots as different ways of forming territory. For nearly a century a good portion of these events have been recorded in images ranging from silent movies to online videos; they serve as documentation as well as propellers for such events. The ways in which people congregate in public space and participate of these events allow for modes of appropriation of the public in order to form urban territories: modes that are spectacular, carnivalesque or rioting. Film as documentary, fiction or online video, could promote hegemonic discourse or other forms of cultural expression in the city, as well as the constitution of different subjects: subjects as people, crowds or mass participating in forming territories.

Keywords: territories; territorialization and deterritorialization; city; urban space; people; crowds; masses; popular culture; parades, carnivals; exhibitions; media images; movies

Keywords Plus: urban space; social aspects; popular culture; carnivals

\section{Resumo}

A maneira de fazer território no mundo contemporâneo está marcada por dois características do seu novo contexto: o âmbito urbano e o uso de novos meios e tecnologias das comunicações. Em Bogotá, identificam-se no espaço público urbano de maior significação histórica e cultural - o conjunto da Carrera Séptima e a Praça de Bolívar - eventos públicos como procissões, desfiles, carnavais, manifestações e revoltas, os quais constituem diferentes formas de fazer território. Durante quase um século, grande parte deste tipo de eventos têm sido registrados em imagens tão diversas como o cinema mudo ou o vídeo na Internet. Observa-se como elas servem como documentos e, algumas vezes, também, como ferramentas para sua realização. As formas como a população se congrega e participa no espaço público de cada evento permitem a apropriação do público e a construção de territórios urbanos na época atual. O cinema de ficção, o documentário e o vídeo na Internet podem promover discursos oficiais hegemônicos e formas diversas de expressão cultural na cidade. Também, possibilitam a constituição de diversos sujeitos - povo, multidão e massa na participação da construção de seus territórios.

Palavras-chaves: territórios; territorialização e desterritorialização; da cidade; do espaço urbano; pessoas; multidões; massas; cultura popular; desfiles; carnavais; exposições; imagens da mídia; filmes

Palavras-chave descritor: espaços públicos; aspectos sociais; cultura popular; carnavais 


\section{¿QUÉ ES HACER TERRITORIO?}

Según Deleuze y Guattari se hace "territorio" en la cantinela infantil con la que el niño se provee a sí mismo un lugar tranquilizador; en la traza cerrada y circular con que se construyen los primeros resguardos de un hogar o las primeras fronteras en la fundación de una ciudad, como también en el rompimiento de esos límites para abrirle paso a algo o salir al exterior. También dan ejemplos de la vida animal, como el del canto con que las aves marcan su territorio: el ritornelo. En todos éstos se da un agenciamiento territorial. Insisten en que el territorio no preexiste, "el territorio es un acto, que afecta a los medios y los ritmos, que los territoriali$z a "$ (Deleuze y Guattari, 2006, p. 321). No se trata del espacio delimitado sino de las acciones con las que es "marcado" en un momento dado, los ritmos y los medios con que se constituye un lugar de expresión. Así, el ritmo nunca tiene el mismo plano que lo ritmado. Debe pensarse en la danza, las máscaras y los trajes que acompañan los cantos rituales; la danza circular que se abre y se cierra para dejar entrar o salir a otros miembros de la coreografía, los colores y los ritmos que trazan y señalan visualmente un territorio cambiante: vibrante. Es pura intermitencia e inestabilidad demandando equilibrio y permanencia en medio de un contexto caótico y fugaz; necesidad de un orden en medio del caos, pero de un orden que juega con su propia fragilidad sin endurecerse, sin cristalizarse ni fosilizarse. Su estado es vibratorio y latente, es puro latir como todo ritmo vital, "hay territorio desde el momento en que hay expresividad de ritmo" (Deleuze y Guattari, 2006, p. 321). Una última afirmación como respuesta a una pregunta: " ¿se puede llamar Arte a este devenir, a esta emergencia? El territorio sería el efecto del arte" (Deleuze y Guattari, 2006, p. 322).

De otra manera, el arte es el orden, ritmo y medios de la música, la danza, la plástica, la arquitectura, que se ejercen al hacer territorio. El territorio es pura expresividad, primero individual y luego colectiva: "es en primer lugar la distancia crítica entre dos seres de la misma especie: marcar sus distancias" (Deleuze y Guattari, 2006, p. 325). Esta distancia interpuesta entre dos seres es ya un acto colectivo, un acuerdo o una imposición entre dos: una primera danza de apareamiento o señales de agresión; instinto, hábitos adquiridos, costumbres colectivas o ritos. El ritual es una celebración que convoca a una comunidad con su memoria colectiva, en el que convergen los relatos fundacionales y mitos en un espacio señalado por mojones e hitos constituyendo un territorio que le pertenece. Relato y memoria se hacen presentes a través de cantos, danzas, máscaras, arquitectura y otras expresiones. El espacio funcional y cotidiano se transforma en territorio de un evento pleno de símbolos y sentidos para una comunidad. Para Ticio Escobar, el ritual expresa la creación artística de una comunidad, de un pueblo:

La celebración ritual intensifica, remata y sobrepasa la experiencia comunitaria; en su representación convergen, potenciadas, las diferentes manifestaciones estéticas (elementos visuales, danzas, música y representación). (2008, p. 57)

En estas formas de hacer territorio, que actualizan el pasado común de una comunidad, emergen las primeras manifestaciones artísticas del ser humano: la danza, la música, el ritmo, el pintarse el rostro y el cuerpo, que suelen identificarse hoy como expresiones tribales y primitivas. Incluso se habla de tribus urbanas para referirse a las costumbres de bandas de jóvenes en las ciudades, como las de hippies o punks, o el hip hop que se expresa a partir de ritmos musicales como el rap y las mezclas electrónicas, danzando el breakdance, vistiéndose 
de manera diferente, señalando el cuerpo con piercing o tatuajes, y el espacio con grafitis. Marcan así claramente su territorio a partir de sus medios y modos de expresión.

Estas formas expresivas de comunidades de jóvenes urbanos pueden asimilarse a otras más tribales y primitivas, por la decisión y acción colectiva de marcar un territorio común y propio donde se exprese su identidad como grupo, por su forma particular de territorializar. ¿Son primitivos y tribales estos patrones y funciones al hacer territorio? ¿Son incluso prehumanos? ¿Son los mismos con los que se expresa la sexualidad, la agresividad y el gregarismo en los animales? ¿En qué se parecen y distinguen estos modos de hacer territorio de los que aparecen en las ciudades contemporáneas? Las expresiones juveniles urbanas son una producción colectiva, fruto de la necesidad de diferenciarse de otros y de identificarse local y generacionalmente entre ellos, con su propia historia, memoria y relatos. Éstos son signos y huellas que no fueron realizados en la jungla o en las cuevas, sino que se realizan en espacios de la ciudad, constituyendo gestos y expresiones, formas de marcar distancias con ritmos espaciales y temporales, entre los individuos y grupos de una colectividad urbana moderna.

Toni Negri define su concepto de "multitudo", en relación con el arte, como la construcción que se realiza a través de una producción colectiva que libera fuerzas de trabajo en una creación liberada de la producción del capital ajeno y del mercado (Negri, 2000, p. 62). En la ciudad y el arte contemporáneo se expresan fuerzas que buscan liberar el objeto artístico de la situación de fetiche y mercancía en que lo ha sometido la forma de producción capitalista y el culto de un arte alienado de la vida. En instalaciones y performance, en las derivas situacionistas, en las prácticas de inserción o la estética relacional se expresa la necesidad de actuar colectivamente en el mismo ámbito de la vida, procurando acciones que se escapen de los circuitos del mercado del arte. Expresiones urbanas como el hip hop u otras formas en que distintos grupos ocupan temporalmente el espacio público dándole otros usos a la calle, el parque, la plaza, el muro o el andén, para expresar su identidad, manifestar sus creencias o inconformidades, son construcciones colectivas asimilables a formas de hacer territorio. Necesariamente el territorio termina por ser construcción colectiva. Negri afirma que no hay producción sin colectividad, de la misma manera que no hay palabras sin lenguaje. El arte es un excedente de trabajo colectivo, abstracto y complejamente significativo, es producción colectiva que asume la liberación y la belleza como resultados. La multitudo encuentra en el arte un medio para realizarse: "a través del arte el poder colectivo de la liberación humana prefigura su destino" (Negri, 2000, p. 62).

\section{¿CÓMO SE HACE TERRITORIO EN LA CIUDAD?}

Con la elección y emplazamiento de unas primeras piedras se constituyen las marcas que circunscriben un espacio cerrado: abrigo rocoso, menhires y dólmenes, monumentos funerarios, observatorios celestes, campamentos primitivos 0 , más tarde, murallas y puertas de poblaciones. Con estas piedras se demarcan y construyen las primeras urbanizaciones (del latín urbs), dentro de las que se empieza a dar una vida protegida de la azarosa aventura del primer cazador nómada, más sedentaria y con una organización social más estable en las que las costumbres primitivas tienden a convertirse en normas. En la urbe se edifican puertas y murallas para abrirla y cerrarla al exterior, y en su interior viviendas, despensas y mercados, talleres y edificios públicos, calles, parques y plazas, que ordenan el espacio en público y privado, de circulación o reunión, etc. En su interior se consolidan formas particulares de vida: 
de trabajo derivado de la caza y recolección de frutos de la tierra, de organizaciones en clanes, de protección frente a peligros exteriores, de jerarquías sociales, de creencias religiosas, de comunicación y lenguaje, de códigos y normas de apareamiento, de intercambio de productos y servicios, de sepultar a los muertos. Al conjunto de unas formas particulares de habitar un territorio y relacionarse entre quienes lo habitan se le ha definido como cultura, siendo ésta definitiva en la constitución de una civilización (del latín civilitas), que puede ser definida como el conjunto de costumbres cultivadas en una gran ciudad o una alianza de ciudades (del latín civitas). La urbanización entonces construye e impone distancias y fronteras entre sus habitantes y la naturaleza y costumbres salvajes o bárbaras de quienes viven fuera de la ciudad (del latín barbárus) o los que provienen de urbes extranjeras (del francés antiguo estrangier). La ciudad produce con la práctica de sus costumbres una diferencia distintiva con los "otros", definiendo una identidad propia: un "nosotros". Se antepone una doble distancia: una física, mediante sólidas construcciones, y otra cultural, mediante costumbres codificadas y diferenciadoras: gestos, lenguajes, formas de actuar, vestirse, regularse, etc. Si en la modernidad ciudad y urbe tienden a significar lo mismo, se hace aquí una diferenciación que corresponde al significado contemporáneo de las acciones de civilizar y urbanizar, aunque en esta última se encuentra la misma raíz para urbanidad.

En la ciudad hay marcas y distancias territoriales establecidas permanentemente a partir de hitos (del latín fictus: fijo), una urbanización espacial con delimitaciones y accesos entre el interior y el exterior, entre lo público y lo privado, y otras inmateriales y duraderas, las creencias y costumbres que reproducen una civilización a partir de rituales cotidianos o ceremoniales (del latín ritus: costumbre o ceremonia). Los hitos y monumentos se instauran en el espacio público, que en palabras de García Canclini es aquello "que no es de nadie en particular pero es de 'todos'" (1989, p. 178). Estos bienes comunes son seleccionados y cuidados por el gobierno de la ciudad como patrimonio, con el propósito de imponer a través de ellos una lectura, memoria e identidad colectiva. También se ha instituido una categoría de patrimonio inmaterial para preservar ciertas prácticas y rituales, pero se olvida que éstas sólo han podido sobrevivir adaptándose a nuevas necesidades de la comunidad, modificando e incorporando otros usos a la tradición. Ambos, hitos y ritos, permiten representar en el espacio y mediante actos las leyendas y relatos fundacionales de una comunidad, los mitos que le han venido dando sentido a través del tiempo (del griego mitos: leyendas). Tampoco éstos son el fiel pasado de una comunidad, "sino el producto de operaciones de selección y trasposición de hechos y rasgos" (García Canclini, p. 177). Éstos le hablan a su comunidad de circunstancias presentes, sea una modificación constante y colectiva, o dirigida por quienes conservan un patrimonio como arma de poder. En la urbs se construyen y conservan los hitos y mojones fundacionales de la ciudad, y la civitas divulga y actualiza los mitos y leyendas de su fundación mediante la práctica de ciertas representaciones rituales. El agenciamiento del territorio de la ciudad comprende: la construcción de un orden físico, visual y plástico del lugar (desde los banderines de colores en la fiesta hasta la conservación de espacios oficiales como las plazas principales o de fundación); una gestualidad rítmica del cuerpo mediante uniformes y disfraces, y marchas y danzas; y un tiempo pasado que es evocado mediante otra reiteración rítmica (relatos, cantos y ritornelos). No sería tan eficaz relatar o representar un mito en un espacio alejado de éste: la maloca, la iglesia o la plaza principal. El carácter de un lugar (del latín locus) permite una resonancia nemotécnica y simbólica a partir del espacio, la ceremonia y la historia contada, que hace que aparezca y se renueve el origen y el sentido de una comunidad. 
Hitos, ritos y mitos se conjugan en una importante función para la comunidad: construir, reinstaurar y rememorar su sentido de vida colectiva y una relación de pertenencia con su territorio. Al gobierno también le sirven para legitimarse a partir de la versión que se quiere preservar de estos relatos, monumentos y rituales como patrimonio. García Canclini explica el patrimonio cultural como un "recurso para reproducir las diferencias entre los grupos sociales y la hegemonía de quienes logran un acceso preferente a la producción y distribución de los bienes" (1990, p. 182). La actualidad y uso de una producción colectiva y simbólica oscila entre los intereses de una curaduría oficial y conservación patrimonial que legitima un gobierno, y la apropiación y resignificación de estos bienes para expresar los deseos, los temores y la identidad de una comunidad. Es una dialéctica en la que las comunidades ejercen una fuerza a partir de su intervención y apropiación, de sus mediaciones; en palabras de Martín-Barbero: "No es posible un desde arriba que no implique algún modo de asunción de lo de abajo" (1998, p. 133).

\section{¿EN QUÉ ESPACIOS URBANOS SE HACE TERRITORIO?}

Existen dos tipos de espacios públicos en la ciudad: las plazas y parques, y las calles y avenidas, que Juan Carlos Pérgolis distingue por su diseño y funcionalidad: "los que invitan a permanecer en ellos y los que sugieren el movimiento" (2000, p. 36). La plaza principal, además de acoger y reunir a los ciudadanos, se define por estar rodeada de edificios representativos de los poderes y algunos monumentos emblemáticos. En la plaza mayor de distintas capitales latinoamericanas se han construido las sedes de los poderes religiosos y civiles, según las Leyes de Indias: la catedral en el costado oriental, y en los otros costados el capitolio, los palacios de gobierno, de justicia o la alcaldía. La calle mayor, además de haber sido diseñada para desplazarse, es también la comunicación entre la plaza mayor y algunos de los accesos más importantes de la ciudad, sirviendo así en ocasiones para que una congregación se reúna y dirija hacia la plaza. En estos dos espacios públicos de la urbe suelen realizarse eventos en los que la comunidad expresa con sus propios ritmos y formas sus creencias, ideales, deseos y temores.

En Bogotá, la carrera séptima entre las calles 26 y décima -esta última es uno de los costados de la Plaza de Bolívar- es el lugar de circulación más concurrido: el llamado septimazo. Pero sus 16 cuadras también han sido la sede y escenario tradicional de distintos eventos religiosos, civiles o militares, institucionales o populares, programados oficialmente o de manera espontánea. Se llevan a cabo desde ceremonias institucionales, como las procesiones del Corpus Cristi o los desfiles militares del 20 de Julio o el 7 de Agosto, hasta los festivos carnavales de estudiantes durante los años veinte del siglo XX o las inauguraciones del Festival de Teatro de Bogotá; sucesos públicos como la llegada del ejército libertador o las marchas de protesta que llegan hasta la plaza; acontecimientos políticos como el quiebre del florero de Llorente en una de las casas esquineras de la plaza el 20 de julio de 1810, el emblemático Bogotazo del 9 de abril de 1948, o la toma del Palacio de Justicia en noviembre de 1985. Este espacio permite a la comunidad rememorar su historia oficial a través de eventos, expresar sus deseos e insatisfacciones en los carnavales, intentar transformar su destino mediante manifestaciones de descontento o propiciar grandes acontecimientos políticos. La carrera séptima se convierte fácilmente en escenario de desfiles, fiestas o marchas de protesta que se dirigen hacia la Plaza de Bolívar donde están las sedes de los poderes religiosos, políticos y judiciales: 
No hay lugar del país donde hayan ocurrido -y ocurran- tantos acontecimientos (...). El ámbito que muestra el sentido de la vida urbana y nacional, que reúne en sus fachadas a los poderes de la ciudad y de la nación, a la Colonia con la República y con la ciudad moderna, al poder de la iglesia con el civil; a lo cercano de la ciudad con lo lejano de los confines del territorio nacional, a lo especial con lo cotidiano. (Pérgolis, 2000, p. 36)

La unión de estos dos espacios conforman el lugar más marcado culturalmente de la ciudad y el país, testigo de acontecimientos protagónicos de su historia, sede para la celebración oficial de sus creencias y ceremonias conmemorativas, espacio de manifestaciones y confrontaciones políticas. Aquel es un territorio de representación oficial del Estado, demarcado por el orden arquitectónico y permanencia de sus edificios y el emplazamiento de monumentos de carácter simbólico nacional, pero también es sede de conformación de distintos territorios, mucho más efímeros, constituidos por los órdenes de marchas, emblemas, uniformes, disfraces, pancartas, cantos, gestos y acciones improvisadas. La calle real se ha transformado en avenida séptima: de las mulas y carrozas al tranvía, y de la quema de éstos el 9 de abril a la proliferación de automóviles, servicios públicos y semáforos, aunque sigue siendo el espacio de las manifestaciones populares de a pie. La Plaza también se ha transformado: del lugar obligado de mercado a su diseño de parque enrejado a final del siglo XIX, parque republicano con cuatro fuentes en la primera mitad del siglo XX y un moderno diseño, mucho más de plaza de congregación de masas, que fue realizado en 1961. La Plaza y la estatua de Bolívar se adecuan y reubican para dar lugar a una renovada función ceremonial. Marcas sobre marcas, gestos borrables sobre hitos perdurables, cantos que quieren intimidar el silencio institucional, danzas sobre el pavimento. Son formas artísticas a las que se atiende o con las que se expresan nuevas voluntades. Ceremonias religiosas y civiles a partir de procesiones y desfiles, fiestas y carnavales en los que se expresan libremente sus pobladores, marchas de protesta que culminan en revueltas, configurando nuevos hitos y mitos para la comunidad, transformando el destino político de la polis.

\section{ALGUNOS EVENTOS EN BOGOTÁ}

\section{Procesiones y desfiles}

Como lo muestran los noticieros cinematográficos de los Hermanos Acevedo, entre 1916 y 1928, las procesiones religiosas de la tradición católica y los desfiles militares que conmemoran la independencia nacional se organizaban a la manera de un espectáculo que sucedía a lo largo de la carrera séptima entre la Plaza de Bolívar y la calle 26, donde aún se conservan partes del Parque de la Independencia. Estos desfiles solían partir de la Catedral y la Plaza hasta la calle 26 para regresar nuevamente, describiendo un movimiento del centro hacia la periferia que retornaba al epicentro, como lugar de origen y constitución del orden establecido (Mora, 2003, pp. 82-84). La procesión del Corpus Cristi salía de la Catedral, encabezada por los representantes del poder eclesiástico y civil, las comunidades religiosas, colegiales y miembros de la alta sociedad encargados de cargar las imágenes religiosas, en un recorrido que continuaba por el centro de la Séptima, dando espacio al resto de la comunidad de feligreses ubicada en los andenes laterales, a veces acordonados o vigilados por la policía. El público 
observaba devotamente el desfile y participaba si mucho arrodillándose, bendiciéndose y contestando rítmicamente las oraciones y letanías. En particular este público son los feligreses.

Los registros cinematográficos de los hermanos Di Doménico desde 1915, y posteriormente de los hermanos Acevedo, documentan los desfiles del Ejército Nacional, que culminaban en una gran parada militar en la plaza, después de que la población contemplara su disciplinada marcha marcial desde los andenes de la Séptima. Como espectáculo la marcha militar se dirige a un público que se reconoce como pueblo soberano, gracias a la gesta del ejército libertador. Este pueblo conmemora su independencia con orgullo y admiración por los héroes. Ambos -procesiones y desfiles- se conforman a la manera de un espectáculo que distribuye las funciones del actuar y el ver en el espacio, siguiendo el orden espacial del teatro burgués: un centro focal para el desfile de las imágenes religiosas o el Ejercito Nacional en la mitad de la calle y la parada militar en el centro de la plaza, y el público en los andenes periféricos de la séptima y la plaza, que en ocasiones se dividía también localizando a los altos mandatarios y sus familiares en una tarima o en el altozano de la Catedral, donde disfrutaban mejor del espectáculo y se alejaban de las muchedumbres. Esta conformación espectacular de la procesión del Corpus Cristi se ve en los primeros registros cinematográficos realizados en 1915 por los hermanos Di Doménico y en los desfiles militares filmados durante los años veinte. Para estas tomas la cámara se situaba en los andenes o antecediendo las procesiones (Nieto, 1992, p. 99).

\section{Fiestas y carnavales}

Los carnavales de estudiantes realizados entre 1916 y el final de los años treinta tienen un carácter muy diferente al de las procesiones religiosas y desfiles militares. Tradicionalmente el carnaval dispone las calles y plazas públicas en un solo espacio homogéneo que anula las distancias y la distribución de roles entre público y actores, pues toda la comunidad se reúne en una sola fiesta. Ya no se trata de una ceremonia oficial sino de una creación colectiva heredada y transformada desde las fiestas pueblerinas y del carnaval medieval europeo. Mijaíl Bajtín (2002) encuentra en el carnaval medieval narrado por el literato francés François Rabelais una cultura popular expresada en los festejos y representación de obras cómicas en las plazas públicas: en las costumbres, el lenguaje de sus personajes, y en la función del carnaval como lugar de la libre expresión del pueblo frente a los órdenes de los poderes eclesiásticos y políticos. Durante la fiesta pública, la representación bufa en exteriores y en el carnaval se subvierte el orden establecido creando un espacio y territorio de licencias para cada uno. Frente a las:

(...) formas del culto y las ceremonias oficiales serias de la Iglesia o del Estado feudal (...), estos ritos y espectáculos organizados a la manera cómica, presentaban una diferencia notable, una diferencia de principio. (Bajtín, 2002, p. 11)

Bajtín señala una "diferencia notable" y "de principios" entre una forma de culto que persiste en instaurar y perpetuar un orden religioso y político, y otra que permite de manera mucho más espontánea la expresión popular de los deseos y temores de los subordinados. Dos tradiciones: una oficial que tiende a fijarse en órdenes y códigos establecidos, y otra que en sus libres y espontáneas variaciones permite expresar las pulsiones de una comunidad; 
una que responde a la necesidad de una clase por mantener un orden político mediante ceremonias oficiales religiosas o militares, y otra a la necesidad por desfogar las tensiones propias del sometimiento de la clase dirigente.

Aunque disten mucho los sujetos colectivos que conforman el carnaval medieval europeo y el carnaval de estudiantes en la primera mitad del siglo XX en Bogotá, se ve en éste una distribución del espacio diferente al de las ceremonias oficiales. Frente al riguroso orden que conformaba un espectáculo que repartía las funciones entre representar y ver en las procesiones y desfiles, en estos carnavales el público abandonaba el andén para transitar alrededor de las comparsas y las carrozas de las reinas, acompañándolas e interviniendo de manera espontánea, tal como se observa en los registros cinematográficos realizados entre 1924 y 1926. Las serpentinas lanzadas desde las comparsas hacia el público y desde éste hacia las comparsas terminan tejiendo una tupida red que cobija en un mismo espacio toda la participación colectiva, en la cual se difumina la frontera entre público y espectáculo. Se ven comparsas que desfilan a pie, otras en carrozas llevadas en automóviles y otras en cabalgatas, confundiendo en una sola colectividad a multitudes provenientes de diferentes lugares: caballos y jinetes que insinúan una población proveniente del campo y sus labores; estudiantes conduciendo modernos automóviles; población de a pie con finos o improvisados disfraces, e incluso familias burguesas que disfrutan del carnaval desde los balcones de sus residencias en plena Séptima. Un elemento importante del carnaval de estudiantes era la elección de la reina de los estudiantes, cuyas candidatas eran muchachas de la alta sociedad que se mostraban al público desde las carrozas y balcones de las residencias vecinas. Pero a pesar de estas diferencias de clases sociales, se construye un orden menos rígido en la participación de toda la colectividad en un ambiente festivo que permite el acercamiento e intercambio entre comparsas y público. Este acercamiento entre clases sociales y la anulación de fronteras entre espectáculo y público que permite la fiesta fue registrada en las imágenes documentales de los Acevedo y de los hermanos Di Doménico y aprovechada también para completar, con otras imágenes de puesta en escena, el largometraje de ficción El Amor, el Deber y el Crimen (1926), de Pedro Moreno Garzón y Vicenzo Di Doménico. Estas imágenes se asemejan a las de una fiesta de pueblo, en la que las clases altas no temen la proximidad de una población, que en términos de la cultura del folklore resulta siendo "pintoresco populacho", o a las del carnaval medieval y popular que sobrevive en la pintura de James Ensor a principios del siglo XX. En ambas parece que:

Los espectadores no asisten al carnaval, sino que lo viven, ya que el carnaval está hecho para todo el pueblo. Durante el carnaval no hay otra vida que la del carnaval. Es imposible escapar porque el carnaval no tiene ninguna frontera espacial. (Bajtín, 2002, p. 13)

Como al hacer territorio, aquí no se erigen fronteras espaciales, se construye a través de medios y ritmos, de determinadas formas de actuar y relacionarse en las que las distancias entre los participantes disminuyen casi hasta anularse, ya no hay público escindido del espectáculo. Dice Bajtín que:

El carnaval no era una forma artística del espectáculo teatral, sino más bien una forma concreta de la vida misma, que no era simplemente representada sobre un escenario, sino vivida en la duración del carnaval. (2002, p. 13) 
Aunque no se puede comparar la forma en que se manifiestan las culturas populares en las fiestas y carnavales de las modernas ciudades latinoamericanas con la de los carnavales de la Europa medieval y premoderna, autores como Néstor García Canclini, Jesús Martín-Barbero o Ticio Escobar han retomado el análisis hecho por Bajtín al carnaval europeo para comprender las formas híbridas con que se realizan algunas festividades urbanas en nuestro continente: lugar de encuentro de diferentes razas y culturas, entre otras la europea, y momento en el que coinciden costumbres y procesos premodernos, modernos y, más tarde, posmodernos. La fiesta popular y pública, con todo lo que significa en su embriaguez dionisiaca, continúa siendo el territorio donde se vence el gran temor ancestral hacia lo desconocido, hacia el otro e incluso hacia sí mismo. Es el territorio de una construcción colectiva de ritmos y modos espontáneos donde lo diverso se expresa en un solo conjunto, donde cada quien expresa y libera su miedo al otro, el deseo de ser otros, y el de ser un solo cuerpo con todos los demás: la afirmación del "nosotros". Para Martín-Barbero es el momento en que:

El lenguaje de la plaza alcanza el paroxismo, o sea, su plenitud, la afirmación del cuerpo del pueblo, del cuerpo-pueblo y su humor. (...) Con sus dos dispositivos claves en la risa y en la máscara. (1998, p. 88)

Se aminoran las distancias con el otro, y mediante el disfraz, la música y el baile se transforma el espacio cotidiano en un escenario donde los temores, los sueños y los roles de cada quien pueden intercambiarse. Es también el momento en que la distancia entre la modernidad y las costumbres atávicas de algunos migrantes se anula, así estén a kilómetros de su lugar de origen. En Bogotá las comunidades oriundas de Barranquilla celebran el carnavalito simultáneamente al carnaval de Barranquilla, y las del Huila las fiestas de San Pedro y San Pablo. Las exigencias de la ciudad moderna no logran excluir las manifestaciones de extranjeros que, a manera de ritornelos, se reterritorializan en la capital mediante la música, la danza, las máscaras y el vestir de las fiestas de sus provincias. Hay quienes desde las capitales viajan a celebraciones tradicionales en sus territorios de origen, para sentir y expresar vivamente su identidad. Escobar cuenta lo que sucede cerca de la capital paraguaya, donde:

En ciertas noches de junio, algunos camareros y crupiers del hotel [Casino, cerca de Asunción] dejan los esmóquines, las mesas verdes y ciertas amables frases en inglés, se hunden en la cercana Compañía Yvyhangu'y, de donde proceden, y allí cubren sus rostros con máscaras pintadas de negro brillante para representar el oscuro y vital rito centenario [de San Pedro y San Pablo]. (Escobar, 2008, pp. 160)

De la tradición ancestral de ofrendar a los dioses con los productos de las cosechas, de hacer pagamentos -en ciertas tradiciones indígenas americanas-, instaurada en el hemisferio norte alrededor del día y noche del equinoccio de verano, y en partes de Suramérica desde la colonización española, sobreviven en poblaciones urbanas diferentes fiestas con nombres católicos. En la noche de San Juan en buena parte de Europa -la noche más corta del año-, todos y cada uno tienen licencia para abandonar su identidad y usurpar otra. Joan Manuel Serrat canta a esta fiesta, en la que: 
El noble y el villano, el prohombre y el gusano bailan y se dan la mano sin importarles la facha (...), en la que comparten su pan, su mujer y su gabán, gentes de cien mil raleas (...), al final vuelva el pobre a su pobreza, vuelva el ricio a su riqueza y el señor cura a sus misas.

(Serrat, Fiesta)

Esta espacio-temporalidad que construye la fiesta está marcada desde el anochecer, cuando "se van [las] miserias a dormir", hasta el amanecer, cuando "despierten nuevamente el bien y el mal" (Serrat, Fiesta), la división de clases y la repartición nuevamente de las riquezas y pobrezas, tanto como los deberes y temores de cada quien. Es la multitud de la fiesta y el carnaval, con sus ritmos, movimientos, colores y cantos, un lugar privilegiado para vencer entonces los temores individuales y colectivos, para aproximarse sin miedo a todo aquel con el que debe mantener una distancia en la vida cotidiana, para que cada uno se presente y represente como desea ser.

Los carnavales de estudiantes de Bogotá terminaron cancelándose a final de los años treinta, entre otras razones por las políticas de salud pública y los intereses de las grandes industrias cerveceras, que celaban la alta producción artesanal de chicha para éstas y otras festividades. En estos años aparece una campaña de desprestigio al consumo de la chicha, con el lema de "la chicha embrutece." Algunos sucedáneos de los desaparecidos carnavales de estudiantes son: los desfiles inaugurales del Festival Iberoamericano de Teatro de Bogotá que se realiza cada dos años desde 1988, y el nuevo Carnaval de Bogotá, institucionalizado por la Alcaldía desde 2005, sin la importancia para la ciudadanía que tenían los primeros, pero ahora con el patrocinio del monopolio de la industria cervecera en Colombia: Bavaria. Ninguno de éstos posee un mínimo de la creación colectiva de los desaparecidos carnavales de estudiantes. En los primeros se instaura la división entre espectador y espectáculo, y explícitamente entre profesionales y público, mientras que los segundos obedecen a políticas culturales gubernamentales que rigen el espectáculo, preservando un orden preestablecido que no permite la intervención espontánea del público. En cambio, los desfiles que ha empezado a realizar la comunidad LGTBI obedecen mucho más a este tipo de creación colectiva en la que se expresan los deseos e identidad de un colectivo abierto a la participación del público.

\section{Manifestaciones y marchas de protesta}

Si en los registros de los carnavales de estudiantes en Bogotá aún podían verse vestigios de tradiciones festivas mucho más provincianas que capitalinas, una relación mucho más directa con el campo expresada en sus costumbres y productos, el acercamiento entre las clases sociales y razas, y la no diferenciación entre público y espectáculo, otras imágenes realizadas un lustro después mostraban el surgimiento de manifestaciones mucho más modernas y metropolitanas. El 9 de junio de 1929 el cortejo fúnebre del estudiante Gonzalo Bravo Pérez se convierte en una manifestación multitudinaria de repudio al crimen. Él fue asesinado por la policía cuando participaba en protestas y manifestaciones públicas en contra de un grupo de políticos corruptos aliados con el alcalde de turno, Ilamado "La Rosca."Tanto las manifestaciones y protestas, como el entierro fueron filmados por Acevedo e hijos. A diferencia de los carnavales de estudiantes en los que las clases sociales se mezclaban en una alegre multitud, el entierro del estudiante se observa como una manifestación masiva solidaria en el dolor y el rechazo a la corrupción gubernamental y la violencia como arma ante las demandas ciudadanas. 
En 1915 se había filmado el homenaje, ofrendas y discursos fúnebres ante el monumento de Rafael Uribe Uribe para el cortometraje El Drama del 15 de octubre, de los Di Domenico; en 1925 los funerales del general Benjamin Herrera con un pomposo desfile y parada militar en la Plaza de Bolívar; y en 1937 los Acevedo filmaron la monumental procesión fúnebre de Enrique Olaya Herrera, cuyo féretro fue acompañando varios días desde su desembarco en Buenaventura, proveniente de Roma, donde el ex presidente murió siendo embajador en la Santa Sede, hasta la Plaza de Bolívar. El entierro del estudiante Bravo Pérez en cambio fue austero pero masivo, no fue llevado a la Plaza sino directamente por la calle 26 al cementerio central de la ciudad. La pomposa manifestación de honores y el carácter ceremonial de los asistentes a las exequias de esos hombre ilustres contrasta con la gran marcha que inunda la calle acompañando el entierro del estudiante. La fecha del 9 de junio se convierte en el día del estudiante asesinado, que se conmemora anualmente con manifestaciones estudiantiles que parten desde la sede de la Universidad Nacional, tomando la calle 26 hasta la carrera séptima y desde ahí hasta la Plaza de Bolívar. Tristemente en la marcha de 1955, en un nuevo enfrentamiento con la policía, muere el estudiante Uriel Gutiérrez y otros compañeros. Las marchas de protestas de estudiantes, empleados y profesores públicos, campesinos o indígenas se dirigen siempre por la Séptima hacia la Plaza de Bolívar, reiterando en estribillos, consignas y gestos, con los que a la manera de ritornelos se caracteriza una forma de construir territorio, hasta convertir la protesta en un reiterado y, hasta convencional, ritual de inconformidad. Las marchas estudiantiles de 2011 contra la reforma educativa propuesta por el gobierno de Santos sorprenden con innovadoras formas de participación colectiva. Al prohibir los carnavales de estudiantes a final de los años treinta, con la excusa de los peligros de la chicha, no se imaginó que esta comunidad encontraría otras formas de manifestarse en el mismo espacio público, más de protesta que de fiesta, o quizá convirtiendo la fiesta en protesta.

\section{Acontecimientos históricos}

La historia de la insurgencia urbana en la ciudad y sus transformaciones políticas se ha hecho hasta mediados de 1948 con escasos registros de imágenes técnicas o sin la colaboración de éstas. El testimonio tanto escrito como en imágenes ha estado a cargo de una historia oficial, que ha silenciado las historias desde las comunidades. El cine, desde El Drama del 15 de octubre, ha buscado representar los hechos históricos dando una versión, que por su alta incidencia masiva es apoyada o censurada por los gobiernos de turno. De otra manera, ha documentado la forma artesanal en que la población convoca a la protesta con carteles y caricaturas de sátira política, como se aprecia en las tomas de las protestas contra "La Rosca" en 1929. Sólo las imágenes de la campaña de Jorge Eliecer Gaitán para las elecciones de 1946 y luego las de las marchas "de las antorchas" y "del silencio" lideradas por él han podido documentar y presagiar uno de los grandes acontecimientos políticos sucedidos en este espacio: el Bogotazo. Tras su asesinato el 9 de abril de 1948 y la revuelta social que se precipita, se filman precarias pero significativas imágenes de un gran hecho político, imágenes que siguen siendo vistas y leídas después de sesenta años del acontecimiento. En la segunda mitad del siglo XX, otros acontecimientos políticos fueron registrados por el cine, la televisión y el video por Internet: la marcha de la Anapo el 20 de abril de 1970, reclamando el triunfo de las elecciones; la toma del Palacio de Justicia por el movimiento 
guerrillero M19 y horas después por el Ejercito Nacional los días 6 y 7 de noviembre de 1985; la "Minga de resistencia social indígena" en noviembre de 2008, cuando llega a la Plaza de Bolívar después de marchar más de 400 kilómetros durante un mes; y los estudiantes en octubre de 2011, con una serie de marchas exigiendo su participación en las decisiones de la reforma a la Ley 30 de Educación Nacional promovida por el Gobierno. Cada vez puede verse cómo los colectivos sociales se apropian de mejor manera de estos medios para la convocatoria y construcción de estos acontecimientos, conformándose como nuevas multitudes.

\section{¿QUIÉNES HACEN TERRITORIO EN LA CIUDAD?}

Durante los años treinta y cuarenta en Latinoamérica, el fenómeno de explosión demográfica urbana y la implementación de modernos medios masivos de comunicación textual, oral y visual -prensa, radio y cine- producen una violenta transformación en sus capitales, tanto en el desarrollo y crecimiento de las urbes como en la forma en que se constituyen como sujetos las clases menos favorecidas. Las costumbres rurales, indígenas y premodernas que sobrevivían en las ciudades tienden a desaparecer o adaptarse a nuevos usos. Las distintas culturas populares y la imagen de nación entran en crisis. Los Estados entienden que tal transformación demanda nuevas formas de intervención social, política, propagandista y policial. La modernización de las infraestructuras y los medios de comunicación serán una herramienta eficaz para alcanzar y controlar la población de sus capitales y territorios nacionales, promoviendo una idea de nación conveniente a sus propósitos de gobierno. Este modelo de modernización o desarrollismo es impuesto en Colombia por los gobiernos liberales de Olaya Herrera, Eduardo Santos y López Pumarejo, que buscaban alcanzar la unificación de las distintas regiones mediante el desarrollo de infraestructuras de obras civiles como ferrocarriles, carreteras, puentes, y de medios de comunicación como la radio. Sin embargo, el paisaje rural y de las pequeñas y medianas poblaciones se modificaba muy lentamente, comparado con el de las grandes ciudades y la capital donde se percibía una gran transformación: grandes obras públicas, crecimiento improvisado y desmesurado en sectores de vivienda, cambios de costumbres de los antiguos pobladores y los inmigrantes campesinos y, sobre todo, las transformaciones de un pueblo en diversas multitudes y de éstas en una gran masa por controlar. José Luis Romero en su estudio sobre la transformación de las ciudades latinoamericanas expresa el significado de este cambio sustancial:

De pronto pareció que había mucha más gente, que se movía más, que gritaba más, que tenía más iniciativa; más gente que abandonaba la pasividad y demostraba que estaba dispuesta a participar como fuera en la vida colectiva. (...) Hubo una especie de explosión de gente, en la que no se podía medir exactamente cuánto era el mayor número y cuánta era la mayor decisión de muchos para conseguir que se contara con ellos y se les oyera. (...) Eran las ciudades que empezaban a masificarse. (1976, p. 319)

Esta transformación la muestra el cine bogotano entre 1916 y 1929: de las imágenes de un pueblo que asiste ordenadamente al culto de las procesiones religiosas o al espectáculo ejemplarizante de los desfiles militares, se pasa a las multitudes variopintas que se expresan en el festín popular jugando a borrar las fronteras entre clases, razas y diferencias culturales, y de esta alegre multitud a la marcha de la masa embravecida que reclama por la injusticia y por 
su dolor. Quizá desde estos momentos la división de clases en la ciudad y la conciencia de una clase oprimida se vuelve irreconciliable; junto a esta identidad colectiva no cesará el temor de la clase dominante, el temor a las masas, la turba o la "chusma", como se llamará localmente. Dos décadas más tarde las imágenes de las marchas gaitanistas y las de su entierro presagian este temor de la clase dirigente y las de la revuelta y vandalaje del Bogotazo lo confirman, a la vez que revelan la confusión y desilusión de una masa que se disgrega en el individualismo.

Hay en el hombre de las multitudes y en la sicología de masas una tensión permanente entre el individuo y sus congéneres, una distancia crítica y tensa dispuesta entre cada centro de percepción, que es un cuerpo, y el resto de individuos que es el conjunto llamado a veces las multitudes, otras el pueblo y otras la masa. ¿Cuál es la colectividad que se constituye como un "nosotros" en los desfiles militares, en los carnavales, en las marchas de protesta o en las revueltas? ¿Quiénes conforman tales modos de hacer territorio en la ciudad? ¿Cuál es el sujeto colectivo y la sicología del pueblo, de las multitudes y de la masa? Hace parte de estas distintas denominaciones la forma y el momento en que cada individuo las percibe: como multitud variopinta, pura pluralidad y diversidad; como pueblo que representa una colectividad que marcha en un solo sentido para alcanzar sus metas; o como masa informe, gris y neutra, que amenaza por su potencia para desbordarse si no se regula y se contiene.

Paolo Virno distingue en la tradición de la filosofía política moderna el origen de esta diferencia en la forma en que Spinoza y Hobbes concebían en el siglo XVIII a las nuevas poblaciones que destronaron las monarquías europeas para constituirse en fuerza(s) emancipada(s) y autónoma(s) ¿multitudes o pueblo? En medio de las transformaciones históricas que marcaron el ocaso de una clase social y de su régimen político, y el nacimiento de las modernas naciones y repúblicas democráticas, el concepto de multitud pensado por Spinoza perdería su oportunidad de realizarse ante el coyuntural concepto de pueblo propuesto por Hobbes (Virno, 2003). En el afán por derrocar el antiguo y consolidar el moderno régimen, se decidió a favor de los grandes consensos, de la voluntad de un único pueblo; no fue el momento de plantear la discusión entre lo diverso y sus disensos, las voluntades de las diversas multitudes. La propuesta hobbesiana de pueblo derrotó históricamente a la spinoziana de multitud. En Multitud, Michael Hardt y Antonio Negri definen los dos conceptos: “El pueblo es uno. La multitud, en cambio es plural. En la multitud (...), las diferencias sociales siguen constituyendo diferencias" (2004, p. 16). Las democracias emergentes decidieron por las mayorías absolutas, o por el absolutismo de las mayorías, sin dar espacio a las minorías disidentes. El concepto de pueblo desplazá al de multitud. Sin embargo, habría otro concepto que ganaría fuerza durante la creciente industrialización del siglo XIX y los fenómenos comunicacionales y políticos del siglo $\mathrm{XX}$ : la masa.

El ensayo sobre la masa que realiza Elias Canetti en Masa y poder es bastante clarificador, al definirla no por su diversidad ni su voluntad unánime, sino por su miedo y el movimiento que este promueve en ella:

(...) nada teme el hombre más que ser tocado por lo desconocido (...). La manera de movernos en la calle, entre muchas personas, en restaurantes, en trenes y autobuses, está dictada por este miedo. (2006, p. 69)

Se trata una vez más de interponer distancias, primero entre aquello que se teme, pero también entre los semejantes. Una de las formas de vencer este miedo a lo desconocido o 
hacia los otros, hacia aquello que puede tocar y herir al ser individual, es afrontándolos colectivamente en masa, traspasando las fronteras de los territorios más íntimos:

Solamente inmerso en la masa puede el hombre liberarse de ese temor a ser tocado. Es la única situación en que ese temor se convierte en su contrario. Para ello es necesario la masa densa, en la que cada cuerpo se estrecha contra otro, densa también en su constitución psíquica, pues dentro de ella no se presta atención a quién es el que se "estrecha" contra uno. (Canetti, 2006, p. 70)

Hay en esta experiencia de eliminar las distancias entre los cuerpos estrechándolos entre sí una forma de psicología que tiende a desplazar el miedo individual hacia una fuerza colectiva y ciega. Es una masa densa y contenida que se manifestará como un ser único en una explosión de pánico, una estampida incontenible o una revuelta que arrasa todo lo que encuentra a su paso. Hardt y Negri distinguen la univocidad del pueblo de la indiferenciación de las masas:

(...) son diferentes del pueblo, ya que no pueden ser reducidas a una unidad o a una identidad única. Es cierto que las masas están compuestas de tipos y especies de todas clases, pero, en realidad, no se puede afirmar que las masas estén compuestas de sujetos sociales diferentes. La esencia de las masas es la indiferenciación: todas las diferencias quedan sumergidas y ahogadas en las masas. (2004, p. 16)

Así, la forma en que colectivamente se hace territorio en la ciudad puede estar marcada por estos diferentes tipos de colectividad: unos que se asumen como pueblo marchando unánimemente hacia un propósito común, otros que se manifiestan espontáneamente con su diversidad de intereses pero unidos como multitud, y los que sintiéndose acosados por sus miedos terminan asimilándose en una sola masa en explosión. Hay en los desfiles y marchas, en las fiestas y carnavales, en las manifestaciones o en el pánico colectivo y las estampidas que suceden en una ciudad, diferentes formas de asumirse como colectividad y de participar en éstas.

Se ve en las imágenes documentales que los Di Doménico y los Acevedo realizaron de las procesiones religiosas y los desfiles militares de principios del siglo XX a toda una congregación que, a pesar de sus diferencias, se dirige hacia un mismo lugar o concentran su mirada en un solo punto: una imagen asumida como una creencia o la de un héroe que representa una historia común. Es la imagen de un colectivo cuya creencia religiosa es la misma que se impuso en la colonización española, y cuya imagen de nación es la que se ha buscado constituir desde las luchas independistas y la instauración de una forma republicana de Estado: un "nosotros" que responde como pueblo. En el conjunto de estas ceremonias se destaca el orden de quienes desfilan y del público: aunque estén separados actores y espectadores, entre ambos existe una comunión, un común ideal, religioso o de nación. La rígida distribución del espacio es consonante con el orden de la procesión, las jerarquías establecidas y el respeto ceremonial con que se llevan las imágenes sacras, o con la estricta disciplina de la marcha marcial, sus impecables uniformes y emblemas, y también su rigurosa jerarquía. El público responde unánimemente con la oración o el silencio. La construcción de nación y de pueblo realizada durante la República deja ver sus resultados en las imágenes documentales de los Di Doménico y los Acevedo. La nación se instituye desde una jerarquía y adiestramiento 
semejante al de la catequesis de la iglesia católica en la colonia, mediante las disciplinas del ejército o la escuela, y sin ayuda de otro medio masivo diferente a la prensa, a la que sólo accedían unos pocos alfabetizados.

En cambio, en los carnavales de estudiantes la población se disgrega y se mueve en distintos sentidos, la división del espectáculo entre actores y público desaparece, aunque el colectivo se mantenga integrado por la fiesta, como un solo cuerpo, pero un tanto esquizofrénico, una locura colectiva que aglutina esta otra forma de un "nosotros". Si los miedos, los deseos y los imaginarios individuales son diferentes, se comparten en una sola multitud, como una molécula que mantiene unidos sus diferentes elementos en una sola fuerza liberadora de energía vital. Como las órbitas que rodean y recorren un átomo, los recorridos de las serpentinas rodean y mantienen a los distintos participantes y comparsas en la unidad del carnaval. La diferencia y el derecho a ejercerla es la razón de ser y la fuerza que mantiene unida a esta colectividad, la fuerza y voluntad de expresar libremente sus deseos: acercarse al otro hasta poder ser uno solo. Aunque resuene el pasado en ella, no es su propósito evocarlo ni celebrarlo, tampoco hay que esperar un futuro, se trata de celebrar la vida en este mismo momento. ¿Hasta dónde son significativos los disfraces y comparsas de marineros, conquistadores españoles, campesinos colombianos? No hay medios masivos que contribuyan a formar tal multitud, sólo el eco de costumbres ancestrales que, sin reglas ni normas pero sí con su ritmo, promueven una gran fuerza expresiva y liberadora. Sin embargo, la fiesta y el carnaval también han jugado una función política de control social: el desfogue energético de las tensiones acumuladas en la vida cotidiana, la ilusión de realizar una comunidad libre y sin diferencias de clases. Esto puede ser, aunque sólo sea durante el carnaval. Las imágenes cinematográficas de éste no sólo muestran un relativo desorden, sino que también es registrado de manera más desordenada que las procesiones y desfiles. Hay más puntos de vista de una cámara que se acerca a las comparsas, está en los balcones, circula en medio de la multitud, etc. El montaje de estas diferentes tomas ya no parece mantener una secuencialidad, quizá porque en el carnaval tampoco es tan clara una sucesión de hechos como en el desfile o la procesión.

Las imágenes en plano general del entierro del estudiante Bravo Pérez muestran por encima a las miles de personas congregadas que inundan la Séptima, en su intersección con la calle 26, y con la ampliación del espacio público que permiten aquí los parques de la Independencia y del Centenario. Ésta es la imagen de la masa aún contenida en el espacio público por las construcciones que lo circundan, pero que parece a punto de desbordarse. La multitud festiva y diversa se ha convertido en masa unánime, cargada de dolor y rencor, conteniendo su fuerza explosiva. Los detalles en planos medios muestran los motivos de su común indignación: rostros, carteles y caricaturas alusivas a "La Rosca", expresiones de repudio y de dolor, son síntomas de una tensión a punto de estallar. Es la masa a punto de convertirse en flujo capaz de correr por las calles como un líquido por sus canales, hasta alcanzar lugares más espaciosos, parques, cementerios y, finalmente, la plaza que siempre quiere ser alcanzada, sitiada y tomada, como símbolo de un poder.

Estas imágenes prefiguran ya las manifestaciones en la Plaza de Toros y las marchas por la Séptima, lideradas por Gaitán a principios de 1948, donde los síntomas de presión y tensión se liberaban, imágenes que advertían su potencia hasta estallar en reacciones: masa en estaIlido. Emblemas de la unidad y de la insurrección popular: los puños, el rostro del líder en contrapicado, su voz ya en el cine sonoro, los rostros de los copartidarios gaitanistas escuchando al caudillo, la masa marchando, los carteles, las antorchas. Lo popular se instaura ahora en 
las masas con la colaboración de estas imágenes mediáticas. Los Acevedo venían cubriendo estas manifestaciones para el Noticiero Nacional que se exhibía como parte de la programación de las funciones de largometrajes. Sucedía lo mismo con el Noticiero Colombia realizado y editado en Medellín por Camilo Correa durante 1947 y 1948. La Semana de la democracia de los Acevedo, sobre la postulación de Gaitán en 1945, y luego las marchas gaitanistas del silencio y de las antorchas mostraban las multitudinarias manifestaciones de apoyo de diferentes gremios, fragmentos de sus discurso, facetas de su campaña publicitaria a través de carteles y movilizaciones populares. Imágenes que expresan un sentir popular inusual en los noticieros y documentales institucionales de esta época: "una conmovedora excepción que de una u otra manera regresa al tratamiento visual y emocional de los primeros años" (Mora y Carrillo, 2002, p. 44).). Desde los años veinte se institucionalizó el noticiero cinematográfico como medio de información y entretenimiento, aunque sólo era exhibido en algunas salas de cine a "incipientes públicos [registrando] los aspectos más generales de la vida de las principales ciudades del país" (Acosta, 2005). A finales de los años cuarenta, las imágenes de estos noticieros contribuyeron a la formación de una identidad nacional y de imaginarios colectivos, como el que alimentó el gran fervor popular hacia Gaitán. Pero quizá el medio que contribuyó más a promover su liderazgo, fuera de la misma plaza pública, fue la radio, donde se transmitían sus emotivos discursos, como los de los "viernes culturales" en el Teatro Municipal. La radio, pese a no poseer el poder cautivador de la imagen cinematográfica, era el primer medio masivo moderno que transmitía en directo, con una inmediatez que servía a la veloz convocatoria de las masas en pro de un ideal común. La voz de Gaitán convocaba masas en el espacio público donde ya se disponían para la acción, pero en colaboración con la radio se transforma la práctica política, asegurando una acción mucho más directa y concreta de hacer territorio.

\section{LOS MEDIOS EN LA CONSTRUCCIÓN DE TERRITORIOS}

Durante los años treinta y cuarenta la transformación de las grandes ciudades latinoamericanas se realizó conjuntamente con cambios de las condiciones de vida de sus habitantes, de la constitución de sujetos colectivos y sus expresiones culturales. La rápida modernización de las urbes y el desarrollo de medios masivos de comunicación generó una violenta ruptura con tradiciones populares convirtiéndolas en objetos del pasado, tenidos en cuenta sólo para superarlos o fetichizarlos. Frente a su ausencia, "lo tradicional" y "lo popular" son usados políticamente por los "elitistas", que buscan preservar la distancia entre las clases imponiendo una frontera infranqueable, o por los "populistas", que aprovechan un sentimiento de nostalgia para promover una identidad nacionalista y atraer a una gran población que siente el desarraigo. Otros se lamentan en medio del desencanto que supone una modernidad arrasadora de las culturas tradicionales, idealizándolas como elementos puros que se contaminan y pierden su esencia al contacto de lo moderno y lo extranjero.

La Escuela de Frankfurt protagoniza la discusión entre quienes afirman que las industrias culturales promovidas por los medios de comunicación masiva degradan las culturas populares y el arte. Éstos no pueden hacer concesiones -Adorno y Horkheimer-, y son quienes argumentan que los nuevos medios de reproductibilidad permiten formas de producción de las que se pueden apropiar las clases sociales para producir un arte político-Benjamin-. El debate es traído por García Canclini, Martín-Barbero y Escobar al contexto latinoamericano, generando nuevas lecturas al problema. La crítica cultural planteada en Frankfurt no se resuelve 
aquí en la radical oposición entre arte o cultura de masas, vanguardia o politización del arte, o, como matiza Umberto Eco, apocalípticos o integrados. El temor europeo ante las industrias culturales y su efecto masificador que puede desplazar lo popular y lo culto es inoportuno en Latinoamérica, después de siglos de colonización, mestizaje e hibridación cultural. García Canclini presenta un contexto en el que no se han excluido lo culto, lo popular o lo masivo, sino que se han conjugado en formas híbridas de cultura en medio de las leyes del mercado: "La modernización disminuye el papel de lo culto y lo popular tradicionales en el conjunto del mercado simbólico, pero no lo suprime" (1990, p. 18). Martín-Barbero ve posibilidades de apropiación y uso de los medios, unas mediaciones en las que sobreviven tradiciones populares, pero de otros modos y con otras necesidades, como "lo popular-urbano en su oposición a lo campesino, el señalamiento de la emergencia de un nuevo sentido de lo popular como lujar de mestizajes y apropiaciones" (Martín-Barbero, 1998, p. 141). En las masas urbanas, lo popular en ves de anularse adquiere un nuevo sentido: "con la formación de las masas urbanas se produce no solo un acrecentamiento de las clases populares, sino la aparición de un nuevo modo de existencia de lo popular" (1998, p. 215). Escobar argumenta que lo colectivo es la característica fundamental de lo popular:

(...) la cultura popular se refiere, así, al conjunto de prácticas de un grupo subalterno que se reconoce como comunidad particular y produce sus propios símbolos o hace suyos símbolos ajenos de acuerdo con sus necesidades colectivas. (2008, p. 114)

Según estos autores se continúan dando formas de expresión de la cultura popular en medio de la modernización y masificación de las ciudades latinoamericanas. La tarea es más bien diferenciar una expresión de lo popular urbano a través de los medios, de una utilización populista de éstos para cautivar a las masas. En términos de Benjamin, una "politización del arte" de un "esteticismo de la política que el fascismo propugna" (1989, p. 57).

Hoy es reconocido el papel que las imágenes en movimiento tuvieron en la movilización de las fuerzas sociales y políticas que contribuyeron al desencadenamiento de la Segunda Guerra Mundial. Los ejemplos de la eficacia y la capacidad del cine de los años treinta y cuarenta para documentar o representar la realidad social en pro de sensibilizar y movilizar masas con las campañas de propaganda política de Alemania, Italia, la Unión Soviética o los Estados Unidos fueron conocidos en su momento en Colombia por algunos políticos. Después de la gloriosa experiencia del cine de ficción colombiano de los años veinte, la implementación del sonido dificultó la producción, definiéndola hacia el documental durante los siguientes veinte años. En palabras del cronista Hernando Salcedo: "hasta que no se demuestre lo contrario, el cine colombiano desde los últimos años de los 1930 hasta los últimos de los 1940 está dominado exclusivamente por los noticieros" (1981, p. 151). Esta producción de imágenes, a pesar de su mala preservación, dan cuenta de las acciones y eventos colectivos en el espacio público. Pero aunque los intereses políticos de Rafael Reyes, Olaya Herrera o Gaitán vieron en el cine una herramienta, ésta no fue explotada en toda su potencia política.

El 9 de abril de 1948 significó entonces muchos cambios profundos para el país: urbanísticos, sociales, culturales, políticos y también del uso de los medios. Las imágenes documentales del Bogotazo mostraron cómo la potencia y fuerza de la masa estalla en la revuelta, imágenes que terminaron por ser testimonio directo e inapelable del acontecimiento histórico, 
marcadas con los indicios que revelan su autenticidad: los de una mirada en peligro que se revela en la brevedad y nerviosismo de los pocos camarógrafos en la calle, o agazapada en los segundos y terceros pisos y techos de edificios en la Séptima y calles aledañas; una mirada urgida por dar cuenta de las acciones que se daban en la calle, pero protegiéndose de la violencia del azarosos devenir de ese presente: la revuelta y el vandalismo. Desde tejados, o detrás de ventanas y balaustras, se filmó la masa indignada marchando con banderas y armas hacia la Plaza de Bolívar o arrastrando el cadáver del asesino Roa, pero también desintegrándose en multitudes que corren atemorizadas por las balas de los francotiradores o se dedican al saqueo de vitrinas y almacenes. Hay imágenes que dan cuenta del caos social que prosiguió a la revuelta: incendios de edificios y tranvías, cuerpos sin vida en las calles, multitudes en huida y otras dedicadas al pillaje, y también los francotiradores atrincherados en la calle o en los tejados; los tanques cubiertos con telas rojas que llegaban a la Plaza de Bolívar engañando a los manifestantes que los acompañan, pues en verdad se dirigían a defender el gobierno de Ospina Pérez. Fueron pocos los camarógrafos de estas arriesgadas imágenes: Camilo Correa, Charles Riou, Marco Tulio Lizarazo y otros extranjeros, como Eduardo Martorell de México y los cubanos del Noticiero CMQ, encargados de reportar la Conferencia Panamericana. Los hermanos Acevedo no coincidieron en ese momento en Bogotá, sólo alcanzaron a filmar el entierro. Fotógrafos como Sady González, Manuel H. Rodríguez o Luis Alberto Gaitán, gracias a la ligereza de sus equipos, documentaron en buena medida los hechos. Estas imágenes fotográficas y cinematográficas, que logran dar cuenta hoy de esta confrontación de fuerzas sociales que fue el Bogotazo, han servido más de testimonio al futuro que lo que en su momento hubiese podido contribuir para convocar y multiplicar las fuerzas.

En cambio lo que sucedió con la radio, que también acompañó el ascenso y asesinato del líder, sí reveló la potencia política de los medios masivos para convocar movilizaciones de masas hacia una acción determinada. La radio participó en el llamando inmediatamente a la ciudadanía y al pueblo a salir a la calle, ir a la plaza y protestar por el asesinato de Gaitán. A pocas horas del asesinato, los poetas Jorge Gaitán Durán y Jorge Zalamea, junto con los profesores Gerardo Molina, Diego Montaña y otros intelectuales, se tomaron la Radio Nacional para invitar a la población a una gran insurrección social, exacerbando su dolor y sentimiento de injusticia. El testimonio directo de estos hechos es dado por los hermanos Raúl y Yolanda Alameda Ospina, en el Documental "Gaitán sí" (1998) de María Valencia Gaitán. Gracias a un contacto mucho más directo con el público, la radio exaltó el ánimo reivindicativo ya cultivado por Gaitán, para alcanzar los objetivos del movimiento social liderado por el líder recién asesinado. Los discursos y arengas desde la Radio Nacional aprovecharon la fe del público en este medio y valiéndose de falsas noticias, como la caída del presidente Ospina Pérez o la unión de varios comandos de policía en el país a la lucha gaitanista, para animar al levantamiento popular. Este caso de apropiación de los medios masivos para la movilización e insurgencia popular sorprende por su temprana data y escasa repetición. Fue una forma de hacer territorio valiéndose de este medio.

Antes de la televisión, entre los años cuarenta y cincuenta, la radio tuvo un papel muy importante en la comunicación social: en el territorio nacional, al llevar la ciudad al campo y el campo a la ciudad, y al interior de la ciudad, al ayudar a conformar un nuevo territorio para aquella población que apenas llegaba del campo. Muchas emisoras acompañaron en su desplazamiento: 
(...) las migraciones a la ciudad durante la violencia de la década del cincuenta (...), las aburridas

tardes de las empleadas del servicio doméstico, las más aburridas noches de los celadores.

(Pérgolis, 1998, p. 41)

Es destacable el papel de una emisora como Radio Sutatenza en la integración del territorio nacional, al atravesar la barrera del analfabetismo, mediante la comunicación oral para enseñar y compartir acerca de las labores del campo y también alfabetizar. Pero este proyecto perdió su gran efecto masivo después de la llegada de la televisión y la comercialización de la radio.

\section{¿CÓMO SE HACE TERRITORIO CON LOS MEDIOS DE PRODUCCIÓN DE IMÁGENES?}

Desde el siglo XIX los medios de reproductibilidad mecánica de imágenes, como la fotografía, la foto impresión, el cinematógrafo, la televisión y el video, gracias a su mayor velocidad, economía y multiplicidad, empezaron a tejer toda una red de comunicación, información y conocimientos sobre el territorio físico. Éstos, además, suponen una importante diferencia con medios más manuales y artesanales, pues con la mediación mecánica se asume ideológicamente una mayor precisión y objetividad en sus resultados. La cámara oscura y el automatismo del registro acrecientan el valor indicial de su imagen: se supone que ésta, más que una representación icónica de la realidad, es un indicio o huella de aquello que estuvo en algún momento frente a la cámara. Este valor:

(...) irreductible del testimonio descansa principalmente en la conciencia que se tiene del pro-

ceso mecánico de producción (...) de su modo específico de constitución y existencia: lo que se ha llamado automatismo de su génesis técnica. (Dubois, 1986, p. 20)

Este supuesto transformó la conciencia del hombre moderno, haciéndolo un fiel creyente de la ecuación entre la realidad y sus imágenes técnicas. La velocidad de circulación y multiplicidad de estas imágenes terminó propagando tal creencia, naturalizándola. A finales del siglo $X X$ y principios del XXI, nuevos medios de producción, circulación y exhibición de las imágenes continúan transformando los modos de percepción y acción del hombre en el espacio-tiempo, urdiendo un denso tejido entre el mundo y la imagen, y en él otra forma de hacer territorio. En su relación con las imágenes, el hombre tiende a no diferenciarlas del mundo, constituyendo un nuevo mundo: la iconosfera contemporánea (Gubern, 1987).

La transformación urbana se da en conjunto con el desarrollo de estos medios, que a la vez transforman los modos de estar, percibir y actuar en el mundo. Pérgolis distingue tres momentos en la ciudad, o tres ciudades en ella misma: la más tradicional y premoderna, una ciudad continua, otra moderna y discontinua, y finalmente una fragmentada, quizá posmoderna. La primera construye su continuidad a través del urbanismo clásico que sabe ligar sus espacios públicos, las calles con las plazas en un regulado tejido. Esta ciudad se aprecia en las primeras tomas de procesiones y desfiles en Bogotá durante los años veintes, con un Parque de Bolívar con fuentes que recuerda las de tantas pequeñas ciudades. El urbanismo moderno con su propuesta de grandes supermanzanas o zonas de funciones como vivienda, trabajo y recreación, y anchas y veloces avenidas produce una discontinuidad en la primera ciudad. Esta ciudad empieza a tejerse a través de medios como el teléfono, la radio, el cine y la primera 
televisión, tejiendo también a través de éstos con otras ciudades. En esta moderna ciudad de masas se destaca el nuevo diseño de la plaza como un gran espacio público despejado y abierto a grandes eventos y acontecimientos. Los aspectos más notables de esta ciudad aparecen en los largometrajes bogotanos de José María Arzuaga. Ahora, desde la aparición de la televisión satelital y de canales comerciales, hasta la actual recepción y manipulación de las imágenes e información por medio de Internet, se densifica el tejido de los medios a la vez que se fragmenta el tejido urbano. Esta ciudad es el ejemplo que estudia Pérgolis en Bogotá fragmentada (1998, pp. 6-15).

La fotografía ha sido siempre una versión o interpretación de lo real, sea su uso consciente o inconsciente, oficial hegemónico o subalterno popular. Desde los retratos de figuras políticas como Tomás Cipriano Mosquera o el general Rafael Reyes, hechos políticos como el ajusticiamiento de quienes atentaron contra el general Reyes o del crimen de Gaitán, la fotografía ha servido siempre para mostrar y también ocultar aspectos de la realidad. Una de estas primeras intervenciones consciente y oficial de la fotografía es la serie que reconstruyó el atentado del general Reyes intentando aproximarse a la vivacidad y realismo de la imagen cinematográfica. En 16 imágenes se ponen en escena los hechos sucedidos -la conspiración, el viaje del general con su hija, y el atentado mismo-, para culminar con 4 imágenes testimoniales del fusilamiento de los criminales en el Panóptico Nacional (Zuluaga, 2007, pp. 20-21). La serie propicia, desde una interpretación oficial de los hechos, una memoria e imaginarios colectivos sobre el mismo territorio urbano. Esta reconstrucción y documentación de Lino Lara sigue la secuencia de las acciones reflejando, a su vez, la continuidad espacial de la ciudad en ese momento: el Parque Centenario, la Bodega de San Diego y el Panóptico Nacional, aledañas a la Séptima, y el Cementerio Central en la calle 26.

Otro caso pionero fue el de la película El Drama del 15 de octubre (1915), de los hermanos Di Doménico, que da cuenta ahora en imágenes en movimiento del asesinato del general Uribe Uribe el 15 de octubre de 1914. Un año después se recrea la historia en los mismos lugares de los hechos, culminando con la filmación en el Panóptico Nacional de los mismos asesinos Galarza y Carvajal. Además, se puso en escena una "alegoría de la libertad" en el mausoleo del héroe en el Cementerio Central. Con una mayor divulgación, gracias a la novedad del cine y al trágico final de los hechos representados, la película afectó sensiblemente al público que comentó: "film inmoral", "exhibición cínica de los asesinos" o "glorificación criminal y repugnante de los miserables asesinos" (Nieto y Rojas, 1992, p. 100). Con estas imágenes se quiso dar una versión no tan oficial de los hechos, pues los Di Domenico buscaban exaltar la figura del líder liberal en medio de la hegemonía conservadora, aunque finalmente su interpretación popular haya sido la de la exaltación del crimen. Pese a la censura pública y la destrucción física de la película, su reacción da cuenta de la incidencia de la imagen cinematográfica en la construcción de una memoria y unos imaginarios colectivos, que se emplazan en el espacio urbano para hacer territorio.

En el tránsito entre el esplendor del cine mudo nacional y la llegada de la televisión, la radio alcanzó su momento estelar como medio de cohesión social. Una importante tradición oral de las culturas populares se reconocía mucho más en las voces de la radio que en los rostros y modas de las películas italianas y norteamericanas importadas por el cine mudo nacional. La voz de los protagonistas de la radio, de los programas musicales y de noticias, y sobre todo de las radio novelas -tan cercanas al folletín melodramático- alcanzó una gran familiaridad con oyentes de distintas clases sociales. Integró el campo a la ciudad y a la ciudad en sí misma, 
cuando su crecimiento demográfico y desarrollo no planificado fomentaban un proceso de discontinuidad en su primer trazado urbano.

En Colombia, la televisión termina heredando mucho más de la radio y sus artífices que de una escasa tradición fílmica. Incluso muchos de los intentos del cine parlante de los años cincuenta son hechos por músicos y protagonistas de la radio. La televisión llega a Colombia en 1954 durante la presidencia del general Rojas Pinilla, creando a su vez un canal para la difusión de la imagen institucional. Desde 1963, el Instituto de Radio y Televisión (Inravisión) tendrá a cargo la construcción oficial de la imagen del país en este medio desde su capital, y sólo años más tarde aumentará su cubrimiento en el territorio nacional. Inravisión emite tradicionalmente las elecciones, posesiones y discursos presidenciales, divulgando la versión oficial que sólo puede ser desmentida públicamente a través de otros medios como la prensa u otras emisoras no oficiales, en las que también opera la censura más tarde. Bogotá creció exponencialmente durante los años en que la televisión alcanzó a una gran mayoría de hogares. Hoy es un medio difícil de intervenir, sino es mediante grandes sistemas de producción que obedezcan a los intereses de los grupos económicos hegemónicos. Sólo queda la posibilidad de intervenciones piratas momentáneas, improvisadas y desapercibidas, o la escasa divulgación de la televisión comunitaria por cable.

El video aparece a final de los años sesenta como un medio independiente de las pretensiones de industria del cine y de la producción televisiva. En un principio se tendrá en cuenta como una propuesta artística de vanguardia, luego se incrementará su uso doméstico, y, finalmente, llegará a la divulgación mediante Internet, con intereses más políticos, en los que se pueden observar sus distintas intensiones en la construcción territorial de comunidades urbanas, indígenas, estudiantiles o juveniles.

En la manera en que "mediante los medios" se hace territorio en la ciudad se distinguen actualmente: un cine de ficción mucho más comprometido con consumos masivos y formas de producción industrializadas; un cine documental, explotado mayormente en sus posibilidades de militancia política enfocadas en la denuncia de la injusticia social y la concientización del público sobre los procesos sociopolíticos; y el video en Internet con una forma de producción, circulación y exhibición más accesible, económica y dinámica en los colectivos y comunidades. Estas tres formas de producción de imágenes se ven en relación con la construcción de territorios en la ciudad, con ejemplos en los que el espacio urbano de la carrera Séptima y la Plaza de Bolívar constituyen su sustancial elemento físico y social.

\section{CONSTRUCCIÓN DE TERRITORIOS EN EL CINE DE FICCIÓN}

El cine tiene su propia forma de documentar, representar, transformar y crear su espacio tiempo. El encuadre de la toma ya limita el espacio entre un campo y un fuera de campo, las diferentes ópticas permiten achatar o dilatar la profundidad del espacio, el enfoque señala distancias de mayor nitidez. También la duración del plano impone un principio y un fin temporal, que puede extenderse o reducirse a través de la velocidad de obturaciones por segundo de la cámara. Sin embargo, es en el montaje en el que estos distintos fragmentos de espacio y tiempo se empatan con otros, donde se construyen nuevas relaciones y ordenamientos espacio temporales. Desde un principio estas posibilidades de alterar y construir un espacio tiempo sorprendieron tanto como la sensación de poder registrar verazmente el espacio tiempo. Quizá fue la observación de su entorno inmediato, la ciudad moderna, lo que permitió descubrir 
posibilidades no concebidas en el diseño general de la cámara y usarlas para registrar el mundo en movimiento de otra forma. Las primeras tomas urbanas, aunque permitían reconocer los lugares, no daban cuenta de la verdadera experiencia de vivir la ciudad moderna, de su dinámica, sus movimientos simultáneos, su permanente transformación, su velocidad, su densidad. A comienzo de los años veinte, el soviético Dziga Vertov reconoció la torpeza de querer obligar al cine a registrar y mostrar el mundo de la misma manera que lo ve el ojo humano, de forzar a la máquina a ver con la imperfección de nuestra vista, cuando le permitía ver de otra forma, revelando aspectos inusitados del mundo que nos rodea. Propone entonces someter el ojo "a la voluntad de la cámara", permitiendo que el "cine-ojo"1 viva y se mueva "en el tiempo y en el espacio y recoja y fije las impresiones de manera muy distinta al ojo humano" (Vertov, 1974, p. 161), y con el montaje del "cine-ojo" construir un nuevo mundo:

Ahora, en el año 1923, tu caminas por una calle de chicago y te obligo a saludar al camarada Volodarski que camina, en 1918, por una calle de Petrogrado y no contesta a tu saludo (...); te he situado, a ti te acabo de crear, en una habitación extraordinaria que no existía hasta ahora y que también he creado. En esta habitación hay doce paredes que he tomado de las diferentes partes del mundo. (Vertov, 1974, pp. 162-163)

En 1929 realiza El Hombre de la cámara, en el que pone en práctica su propuesta construyendo una nueva ciudad a través de la filmación y el montaje de cinco ciudades soviéticas.

Durante su primer siglo de existencia, el cine de ficción ha construido y reconstruido innumerables ciudades, ya sea con la ayuda de escenografías creadas en los grandes estudios cinematográficos -emergentes urbanizaciones en el oeste norteamericano, intrincados y oscuros callejones del mundo criminal, urbes galácticas, luminosas ciudades para coreografías de musicales o la Roma imperial-, o con fragmentos de los espacios reales de Roma durante el neorrealismo, París en la nueva ola, o Bogotá en el cine de José María Arzuaga. Gracias a la imposibilidad económica y técnica de desarrollar una industria cinematográfica en Colombia, el cine de ficción ha debido realizarse en las mismas locaciones de sus ciudades. Cuando se estuvo más cerca de tal pretensión industrial, durante los años gloriosos del cine mudo, se construyeron en Bogotá los estudios cinematográficos en los que se realizaron las escenografías de Aura o las violetas (1924), La tragedia del silencio (1924), Como los muertos (1925), El amor, el deber y el crimen (1926) y Alma provinciana (1926). Estos estudios, construidos en algunas manzanas vecinas de la carrera Séptima, recreaban los interiores y espacios domésticos de la ciudad, ambientes residenciales y laborales que se unían por montaje con espacios públicos como el Parque Centenario, la carrera Séptima, la fachada del Teatro Colón y del Capitolio, y la Plaza de Bolívar. Quizá la más interesante reconstrucción del espacio de la ciudad en este período se dio en El amor, el deber y el crimen, de Pedro Moreno y los Di Domenico, logrando una fluida continuidad entre espacios domésticos en estudio y espacios públicos en las mismas locaciones urbanas -los recorridos peatonales por la Terraza Pasteur en la Séptima o los automovilísticos por ésta y otras calles de Bogotá-, además de mezclar la ficción y el documental. Las imágenes en planos generales del carnaval de estudiantes fueron hábilmente montadas con las de una puesta en escena en planos más cerrados de los protagonistas en medio de una recreación de los mismos carnavales. El documental se integra a la ficción para construir en él un relato. La construcción de territorio que mostraban las tomas del carnaval se 
suma a la construcción del espacio temporal propia del montaje cinematográfico, en un solo continuum narrativo, sin importar que se perciba un comportamiento del público muy diferente, demasiado atentos a la comparsa protagonista en las imágenes de la ficción.

Otras estrategias para acercar la ficción a lo documental son usadas por Arzuaga en sus películas de los años sesenta. Para Raíces de piedra (1961) se siguió a los protagonistas en sus recorridos peatonales desde vitrinas de almacenes, segundos pisos o automóviles, permitiendo ocultar la cámara y hacer un registro de improviso de la ciudad. Un largo travelling lateral sigue a Firulais en una extensa caminada por la Séptima, desde la Avenida Jiménez hasta el Parque Santander, integrando al actor al acontecer cotidiano de esta importante calle. Para otra secuencia se filma desde una vitrina al actor que representa a Clemente, en la carrera décima simulando un ataque y convulsiones que lo tumban al andén. Los transeúntes que no saben que se trata de una película observan al supuesto enfermo y continúan su recorrido sin auxiliarlo. Gracias al performance en el ambiente real, las imágenes documentan la indolencia en esta ciudad. Otra secuencia se filma desde un segundo piso mostrando al actor, que representa a Firulais, huyendo con una cartera robada por una populosa calle céntrica donde finalmente es atrapado por los reales transeúntes de la ciudad. Las estrategias de este tipo de puesta en escena aprovechan la forma natural de ser de las multitudes urbanas, generando un valor documental a la ficción. Para Pasado el meridiano (1966) Arzuaga aprovecha la ubicación del lugar de la historia, una oficina en un edificio situado en la Séptima entre calles 17 y 18 en donde el protagonista es portero, para filmar en medio del tumulto callejero. Las tomas en la séptima son ahora más cerradas, cámara en mano siguiendo al personaje entre la multitud. Éstas son montadas sin pretender respetar el tiempo original de la filmación, como sí lo hacía en la más neorrealista Raíces de piedra. En Pasado el meridiano, hay un tratamiento más audaz del espacio tiempo de la ciudad y de la misma narración con flashback y elipsis. En su documental Rapsodia en Bogotá (1964) reconstruye la ciudad, al estilo de sinfonías de ciudad como El Hombre de la cámara de Vertov, alterando el orden y continuidad espacio-temporal de la ciudad a partir del montaje. La carrera Séptima es reconstruida tanto espacialmente como temporalmente, por ejemplo en el montaje de una serie de tomas de distintos aguaceros haciéndolos aparecer como uno solo.

La utilización de imágenes documentales de acontecimientos importantes en la ciudad para darle un contexto histórico a la ficción es también usada por Jaime Osorio en la introducción de Confesión a Laura (1991), cuando se apropia de varias imágenes del bogotazo, alterando su textura para ensamblarlas en continuidad con el plano en el que aparece el protagonista de la película caminando por la ciudad. Posteriormente la historia va a concentrarse en un mínimo espacio doméstico, teniendo como telón de fondo los acontecimientos del 9 de abril, para lo que se sirve en buena medida de la transmisión radial de éstos.

La estrategia, utilizada por Arzuaga, de filmar con una cámara que pase desapercibida en la calle es recuperada recientemente por Ciro Guerra en La ombra del caminante (2004), aprovechando equipos de video mucho más livianos y manuales que los de cine en 35 o 16 $\mathrm{mm}$. La película se desarrolla en muy buena parte a lo largo de la Séptima, donde uno de los protagonistas trabaja cargando personas en una silla a sus espaldas. La ficción se enriquece con la participación de la multitud callejera, sea espontáneamente o ignorando que la cámara los filma. La secuencia de una redada de la policía a los vendedores ambulantes se dio realmente en medio de la filmación, y después fue complementada gracias a la colaboración de la misma policía. Este tipo de registros dan una cualidad singular a estas imágenes, en las 
que se siente la vida de la ciudad de manera muy auténtica. La intensión de hacer intangibles las fronteras entre la ficción y lo documental fue apropiada con gran claridad discursiva en el cine nacional por Carlos Mayolo y Luis Ospina en Agarrando pueblo (1978). Ésta pone en evidencia la mala conciencia de ciertos documentalistas al filmar aspectos de la dura realidad de sectores marginales y desamparados con el pretexto de hacer una denuncia social, pero cuyo verdadero fin es lucrarse a partir de estas imágenes grabadas sin ninguna sensibilidad de quienes documentan. Una escena de ficción en la fuente de la Rebeca, en plena calle 26 a una cuadra de la Séptima, satiriza sus métodos al mostrar un documentalista lanzando monedas a la fuente, como carnada para que los gamines se bañen en ella. La puesta en escena, en la que el mismo Mayolo hace del documentalista, se mezcla con lo documental: las imágenes en blanco y negro muestran el equipo técnico filmando a partir de estas estrategias, y en color las del supuesto documental. Muestra la deshonestidad de tantas imágenes que con la disculpa de documentar lo social, "al pueblo", lo único que hacen es "agarrarlo" para su propio beneficio, "vampirizándolo", como reconoce el mismo documentalista. La película se realizó de manera independiente, sin un objetivo ni formato comercial, filmada en $16 \mathrm{~mm}$ y con una duración mayor a la exigida para los cortometrajes de sobreprecio que denunciaba.

En la forma de encarar la puesta en escena en el espacio público urbano pueden distinguirse dos actitudes distintas: intentar la construcción de una acción estrictamente prefijada en el guión, a partir de una puesta en escena cerrada a la azarosa vida urbana mediante el acordonamiento de calles y la intervención de extras que simulan ser transeúntes; o usar e inventar estrategias de puesta en escena que permitan mezclar la acción prevista con el imprevisto acontecer urbano. En la primera están sobre todo las reconstrucciones históricas de momentos de la ciudad, como el bogotazo en La Historia del baúl rosado (2005) de Libia Estela Gómez y Roa (2013) de Andy Baiz, o los años ochenta de la tragedia de Armero y el crimen de Pozzeto en Soplo de vida (1999) de Ospina y Satanás (2007) de Baiz. La recreación de la vida urbana en pleno centro de la ciudad está regida por las necesidades argumentales y dramáticas del guión y por las intensiones estilísticas del director, que casi siempre busca un ejercicio de estilo relacionado con los géneros de Hollywood o la industria cinematográfica internacional. Juana Suárez (2009) resalta cuatro largometrajes de ficción situados geográficamente en el centro de Bogotá, como exponentes del cine negro: La gente de la Universal (1994) de Felipe Aljure, Soplo de vida, Perder es cuestión de método de Sergio Cabrera (2004) y La historia del baúl rosado (p. 163). Habría que agregar Satanás y Roa. La vida pública de la ciudad recreada en ellas tiende a revelar su propia falsedad, obviamente la de la ficción: en las cuatro aparece una carrera Séptima en la que se reconoce sobre todo su espacio urbano y arquitectónico, más que las reales formas de vivir y habitar la ciudad. Pero toda ficción es a su vez su propio documental, su detrás de cámara. Suárez observa en éstas el centro como "un espacio de resistencia que escapa, por lo menos parcial y provisoriamente, al dominio de la lógica neoliberal" (Suárez, 2009, p. 166).

Pero el retrato de formas de resistencia en medio de la ciudad abierta en su pleno centro es más dinámico y veraz en las producciones que también se abren al azar de la misma vida urbana, donde la ficción permite ser permeada por lo documental; lo que sucedía en el cine de Arzuaga es también lo que sucede en La gente de la Universal, La primera noche (2003) de Luis Alberto Restrepo, La sociedad del semáforo (2010) de Rubén Mendoza y la mencionada La sombra del caminante. Éstas narran historias contemporáneas al momento de su realización, que permiten hacer una puesta en escena en medio de la ciudad actual. La primera es 
una producción con bastante control de lo que sucede en las locaciones donde se filma, la Séptima desde la calle 28 hasta la Avenida Jiménez, en lugares característicos como el Parque Santander o el Museo Nacional, pero aprovecha personajes, costumbres y sucesos de este espacio público, como el artista callejero con su mascota. Estos lugares son mostrados como espacios de la sobrevigilancia urbana posmoderna, transformándose en vitrinas, jaulas, acuarios, desde donde los protagonistas se vigilan entre ellos. La primera noche busca documentar a través de una historia de ficción la llegada de una pareja de campesinos a la ciudad. El lugar de la puesta en escena es la fachada del Teatro Olympia, esquina de la octava con calle 26, en medio de la fría noche bogotana. La condición de la soledad nocturna en una calle del centro de la ciudad hace verosímil rodar sin transeúntes ni extras. Para La sociedad del semáforo Mendoza recurre a una anécdota ficticia que surge de observar el ingenio de quienes se dedican al "rebusque", aquellos habitantes de la calle que trabajan en los semáforos y construyen ahí sus territorios, o, en sus palabras, "el parche." Son vendedores ambulantes y artistas callejeros que se ingenian mecanismos para aprovechar el tiempo detenido de los transeúntes en los semáforos y realizar breves espectáculos. La pregunta y propuesta del protagonista es ¿cómo obtener un excedente de tiempo del transito urbano para realizar su trabajo? El trabajo colectivo con actores no profesionales en esta película reproduce dentro de la ficción la solidaridad con que estos habitantes se organizan y construyen sus territorios. El protagonista recorre la Séptima y el Parque Santander, donde le enseñan un cd pirata del silencio, demostración del poder transformador del cine en la reconstrucción del espacio en tiempo real: la imagen del centro de la ciudad al omitir el sonido ambiente natural de ruidos, muchedumbre y tráfico urbano, es otra. Sin embargo, para la puesta en escena de la ficción, aunque se busca representar el fenómeno real de estas comunidades y se cuente con actores no profesionales salidos de la misma calle, se debió recurrir a acordonar los espacios donde se estaba filmando, separando la realidad de la ficción.

Estas últimas propuestas de puesta en escena, que intervienen de la manera más directa en la vida cotidiana de la ciudad, permiten quizá mostrar un pueblo o las multitudes callejeras, que suelen permanecer ausentes en el cine de ficción. Deleuze pone en duda la idea de que el cine, como arte de masas, sea "el arte revolucionario o democrático por excelencia haciendo de las masas un auténtico sujeto" (1987, p. 287), al observar cómo los poderes hegemónicos logran tomar para su beneficio a estas masas, haciendo un arte populista, antes que popular. La misma historia del cine mostró como:

La aparición del hitlerismo que proponía como objeto del cine no ya las masas en condición de sujeto sino las masas sojuzgadas; el stalinismo que sustituía el unanimismo de los pueblos por la unidad tiránica de un partido; la descomposición del pueblo americano, que ya no podía considerarse crisol de pueblos pasados ni germen de un pueblo venidero. (Deleuze, 1987, pp. 286-287)

¿Dónde está entonces el pueblo en el cine? ¿Cómo puede participar en alguna forma de la producción cinematográfica? El neorrealismo es uno de los pocos casos que permite una respuesta afirmativa, y el de quienes siguen su ejemplo en el cine contemporáneo: el cinema novo brasilero, el cine iraní, el cine de Víctor Gaviria, el de Arzuaga y quienes se consideren sus herederos. De otra manera, un cine político moderno tendría que ser el que se pregunte dónde está el pueblo, un cine que muestre que "el pueblo falta" (Deleuze, 1987, p. 287). De lo 
contrario, el cine de ficción tan determinado por su forma industrial de producción sólo busca al pueblo en la sala de cine, es un cine populista. Sólo alejándose de este modo de producción y mezclándose en la calle con el pueblo, las multitudes y las masas, podría construirse un territorio haciendo "parche" con ellas. Quizá el ejercicio de cierta forma de documentales pueda dar cabida al pueblo ausente o evidenciar esta ausencia.

\section{EL DOCUMENTAL: DEL REGISTRO A LA PARTICIPACIÓN}

El cine documental, antes que pretender construir un nuevo espacio tiempo, busca documentarlo en su relación con el hombre: el de Nanuk en el paisaje ártico construyendo su iglú o la del $k i n o k l^{2}$ en la nueva urbe soviética construyendo el cine-ojo. El cine documental ha querido dar cuenta del hombre construyendo su territorio. En el caso del documental urbano, registra, representa o construye territorios en relación con las masas, las multitudes o el pueblo. Desde hace más de un siglo este cine ha venido registrando diferentes formas de agrupaciones colectivas en Bogotá: marchas y desfiles, fiestas y carnavales, estampidas y revueltas. El documental ha sido el medio ideal para registrar la composición rítmica del espacio al hacer territorio en la ciudad, y también para construir con sus propios ritmos temporales: el tempo de las marchas, las pausas en los desfiles, los ritmos musicales de las bandas, las complejas coreográficas de las fiestas, las espontaneas irrupciones en los carnavales y estampidas, los movimientos de contracción y distención de las masas en las revueltas callejeras. Habría así un documental que sólo intenta hacer el registro de los acontecimientos y otro que, viéndose involucrado en el mundo, prefiere participar en éstos. Bill Nichols define cuatro categorías del documental: discursivo, observacional, interactivo y reflexivo (Nichols, 1991, pp. 65-106). Los documentales de los hermanos Acevedo y Di Doménico durante los años veinte y treinta, y luego los de los camarógrafos que se arriesgaron al registrar los sucesos del 9 de abril, daban cuenta de los eventos y acontecimientos, creyendo tener una visión neutra de éstos. Esta forma corresponde por su ingenuidad a la primera denominación de Nichols: el documental discursivo. Sin embargo, un buen análisis crítico revela en ellos el lugar de una mirada no neutra: oficialista en las procesiones, desfiles y carnavales; clínica en el entierro del estudiante Bravo Páez; en peligro o accidental en las del 9 de abril (Nichols, 1991, pp. 119-129).

El primero de abril de 1937 Carlos Schroeder y Gonzalo Acevedo presentan el invento y primer ensayo del cine sonoro en Colombia, que pondría fin a las imágenes silentes que circularon en los noticieros colombianos desde 1916 hasta 1937. También son los noticieros, y los documentales que devienen de éstos los primeros que toman voz y discursividad durante los siguientes años. La voz del "pueblo", como se autoproclamaba Gaitán, se difunde en las plazas, en la radio y acompaña ahora las imágenes de los noticieros en su candidatura para las elecciones de 1946, los discursos y manifestaciones en la Plaza de Toros y el Teatro Municipal, la marcha de las antorchas y la del silencio a comienzos de 1948, y su famosa Oración por la paz, el 5 de febrero de este año. Jorge Eliecer Gaitán conoció Italia en tiempos de Mussolini y conoció la incidencia de los medios en las masas y, por ende, su potencial político. En 1942 como Ministro de Educación emprende un original programa de cine educativo ambulante y promueve la primera ley de cine en Colombia. Luego, el 9 de abril de 1948, Gaitán se convierte en imagen emblemática para la ciudad, el país y el desarrollo de los medios; quizá no haya otra imagen mediática de un político que haya trascendido tanto como la suya. El quiebre del cine mudo al sonoro en el país coincide con la desaparición de las imágenes de las multitudes 
silenciosas y la aparición de las masas alentadas por la voz del líder. La radio, en primer lugar, y luego el cine parlante serán las armas de Gaitán, pero tras su asesinato sólo se dio la apropiación popular de la radio, pues el cine ante el peligro callejero se vio obligado a registrar los acontecimientos mientras se protegía.

Un cine documental con una conciencia explícita de transformación social aparece en los años sesenta y setenta, en el contexto y en comunicación con los distintos exponentes del nuevo cine latinoamericano: Gabriela Samper, Carlos Álvarez, Martha Rodríguez y Jorge Silva, Carlos Mayolo y Luis Ospina. La primera abordará temas más rurales, el segundo emprenderá un cine militante y partidista, los terceros un compromiso antropológico y ético con sus sujetos, y los últimos harán una contrapropuesta a la falsa moral y política de un degradado cine de denuncia social. Todos estos cineastas hacen parte de otras categorías en la teoría de Nichols: la de un cine interactivo y quizá reflexivo. Colombia 70 (1970) de Álvarez es el retrato de una habitante de la calle 19 con séptima, duramente escudriñada por una cámara no oculta y confrontando su triste rostro con un montaje de insertos de imágenes publicitarias de Kodak. En ¿Qué es la democracia? (1971), Álvarez sigue la jornada electoral del 19 de abril de 1970 en espacios como la Plaza de Bolívar. En la noche se suspendió la información del conteo de votos, sembrando la duda sobre la legitimidad de las elecciones y generando la reacción de Acción Nacional Popular ANAPO, partido del derrotado general Gustavo Rojas. El 20 de abril la manifestación contra el fraude electoral que se dirige por la Séptima hacia la Plaza de Bolívar fue reprimida y disuelta por la acción de la policía. En medio de la protesta, la cámara de Álvarez documenta y marcha entre la masa, tomando un deliberado punto de vista sobre el acontecimiento. En la primera parte un discurso voz en off explica cómo funciona la democracia en Colombia y en la segunda da cuenta de los sucesos comentándolos con algunos intertítulos: "20 de Abril", "Calma". El uso de la cámara, la voz en off, el montaje y los textos, en el registro de las dos jornadas -la primera de manera más discursiva y la segunda más participativa- hacen explicita la posición política del autor frente a los hechos. Deja de ser testigo neutro para convertirse en actor social, su cámara se acerca a las masas, su voz toma partido, el montaje crea relaciones discursivas. Los postulados del Tercer Cine Colombiano redactados por Álvarez en 1968 eran: "ser un cine político", "de 4 minutos", "hecho con mínimas condiciones", "documental" y "terriblemente dialéctico" (1989, p. 95). Un cine que fomente "un diálogo abierto entre el público y el film y entre los espectadores mismos": "films "incompletos", más bien "provocadores", que apenas enunciaban el problema y que eran "completados" por los espectadores" (Álvarez, 1989, p. 96). Este cine de acción y participación colectiva dialoga con las propuestas del Tercer Cine de Octavio Getino y Fernando Solanas, de quienes Álvarez tenía una copia de La hora de los hornos (1968) que mostraba en colectivos de sindicatos, obreros, campesino y estudiantes, con los que se discutía la película después de la proyección. La hora de los hornos contenía además las discusiones que se daban después de sus proyecciones, y que fueron filmadas y montadas en el metraje de la película por Solanas. Se trataba de una obra en marcha que se sumaba a la acción política, una construcción de territorio en el que participaba un cine autodefinido como urgente, de acción y colectivo. En el manifiesto Hacia un tercer cine, Gettino y Solanas lo definen como:

Un cine guerrilla, o cine acto, con la cantidad de categorías que contiene (cine-carta, cinepoema, cine-ensayo, cine-panfleto, cine-informe, etc.), opone, ante todo, al cine industrial, un cine artesanal; al cine de individuos, un cine de masas; al cine de autor un cine de grupos ope- 
rativos; al cine de desinformación neocolonial, un cine de información; a un cine de evasión, un cine que rescate la verdad; a un cine pasivo, un cine de agresión; a un cine institucionalizado, un cine de guerrillas; a un cine espectáculo, un cine de acto, un cine de acción; a un cine de destrucción, un cine simultáneamente de destrucción y de construcción; a un cine hecho para el hombre viejo, para ellos, un cine a la medida del hombre nuevo: la posibilidad que somos cada uno de nosotros. (1969, p. 60)

Para Álvarez, el tercer cine:

Ya no era la relación pasiva del cine-espectáculo-prostitución con el público-espectador-cliente. Ya el cine no era para mirar pasivamente la realidad; era para que cine y espectador participaran en ella. Participaran y la cambiaran. (1989, p. 62)

Su película ¿Qué es la democracia?, más que mostrar los hechos políticos, demandaba respuestas y acciones de un público que, como en La hora de los hornos, debía comprometerse políticamente con el cambio de su realidad social.

El 6 y 7 de noviembre de 1985 tiene lugar otro acontecimiento en la Plaza de Bolívar y será registrado esta vez por la televisión nacional y otras cámaras de video: el movimiento guerrillero M19 se toma el Palacio de Justicia, seguido de la contra toma de la Policía y Ejercito Nacional. Una batalla en pleno centro de la ciudad causó la muerte de cerca de un centenar de personas, en su mayoría civiles. El edificio fue construido en 1971 con un estilo arquitectónico acorde con el de la moderna remodelación de la Plaza de Bolívar. Después de los acontecimientos del 6 y 7 de noviembre permaneció semidestruido y abandonado como un fantasma por más de una década, y el suceso quedó en la memoria colectiva de la nación, en un proceso que aún no se cierra. Las imágenes de lejanos planos generales y acercamientos con zoom, de los soldados descolgándose en helicópteros en la terraza del edificio, las de la tanqueta disparando rocket hacia la fachada del Palacio y violentando su puerta hasta entrar, el rescate de civiles y, más tarde, las llamas consumiendo la mole de concreto, conmocionaron en directo a todo el país. Los disparos e incendio dolían "en la piel de cada uno de los espectadores, que seguían por televisión los acontecimientos de la toma del Palacio" (Pérgolis, 1998, p. 86). Su impacto mediático superó el impacto de las imágenes de los tanques con telas rojas llegando a la Plaza de Bolívar en medio de la revuelta popular del 9 de abril, tanto que la ministra de comunicaciones ordenó suspender la transmisión en directo por televisión y en su reemplazo se emitió en diferido un partido de futbol. Pero a diferencia del efecto de cierta audiencia radial en el Bogotazo, el público televidente del 6 y 7 de noviembre estaba absorto y amedrentado. El efecto de la televisión fue disgregar la masa en pequeños grupos controlables. En consecuencia la reacción ciudadana ha sido tardía: incontables marchas y manifestaciones por los desaparecidos se han dado en el transcurso de los siguientes 28 años, marchas conmemorativas, no protestas y revueltas como las que promovió la Radio Nacional tomada por algunos intelectuales en 1948. También tardíamente la Fundación Patrimonio Fílmico Colombiano hace un tardío homenaje a las víctimas y desaparecidos, editando el material en video del archivo de Gabriel Ortiz acompañado musicalmente por el solemne Réquiem de Mozart, en la pieza Fragmentos Palacio de Justicia 6 y 7 de noviembre 1985.

El documental militante se autopropone como antiespectáculo frente al cine de ficción, como una forma de mostrar la realidad a un público del que se espera una participación activa 
en la transformación de su mundo, al tiempo que la realidad en la televisión oficial y comercial se convierte en espectáculo, para un público disgregado en minorías que parecen absortas en la contemplación y la impotencia. La televisión promueve una versión oficial y monolítica de la historia, mientras el documental independiente, incluso el más dogmático y militante, introduce la contrainformación.

\section{CRÍTICA AL ESPECTÁCULO DESDE LOS TERRITORIOS}

Para la definición de una construcción colectiva o popular a través de los medios masivos debe tenerse en cuenta una forma de producción y resultados, que realmente estén intervenidos por una voluntad, una fuerza o una expresividad "popular". En la modernidad este término se confunde con la producción de los medios masivos, sea por el gran consumo que tengan debido a que divulgan lo ya popular (contenidos populares), o porque los divulguen masivamente las industrias culturales (recepción popular). Pero el producto mediático sólo es expresión popular cuando una comunidad, sea esta urbana, usa los medios de producción para expresar su identidad, sus problemas o anhelos vitales. García Canclini demuestra que en la modernidad latinoamericana dejan de excluirse entre sí lo culto, lo popular y lo masivo, para hibridarse entre ellos. En estas culturas híbridas se encuentra también una función social, tanto en lo subalterno y popular, como en lo hegemónico. Escobar distingue además rasgos de lo popular en las culturas hegemónicas: en la oficial estatal, la oficial eclesiástica, la erudita local, la erudita internacional y la de masas, aunque a esta última se le niegue la posibilidad de una propuesta artística. Pero:

(...) frente a la posición hegemónica, la cultura popular comprende las prácticas y discursos simbólicos de los sectores subalternos; sectores que (...) no terminan de reconocerse en las imágenes hegemónicas ni se identifican fundamentalmente a partir de ellas. (2008, p. 109)

Estos sectores subalternos deben inventar sus propias alternativas para usar los medios y reconocerse a través de sus productos: los pueblos indígenas, los campesinos, las diásporas étnicas, las clases proletarias urbanas, o los jóvenes citadinos que buscan su propia identidad. Martín-Barbero llama "mediación" a la forma como un colectivo se apropia de los medios para producir y expresar de una nueva manera lo propio. Según él, Michael de Certeau narra cómo se dan "usos como operadores de apropiación", cuando obreros u operarios utilizan las máquinas y medios de sus lugares de trabajo para realizar otro tipo de productos que sean útiles para su vida, liberando así "la creatividad castrada por la división y el trabajo en cadena" (MartínBarbero, 1998, p. 112). Éste es un claro ejemplo de apropiación de los medios en función de las necesidades vitales de quienes los operan. Es el caso de los artistas e intelectuales que el 9 de abril utilizaron la Radio Nacional para hacer la programación que consideraban en ese momento la necesaria para el colectivo del que se sentían parte. Ésta es una forma de ser de la cultura popular urbana, una forma de construcción colectiva dentro del espacio urbano y a partir de los medios masivos.

El sentido de ciertas formas de apropiación de los medios y el espacio público fue una clara

contrapropuesta del movimiento situacionista al urbanismo moderno, del que denunciaban su forma de construir y disponer el espacio urbano para capturar la fuerza de trabajo de sus habitantes, concentrándola y maximizándola para la producción capitalista. Los situacionistas conciben 
diversas estrategias: la práctica de la deriva en contra de la circulación que propone el urbanismo

" hay que pasar de la circulación como suplemento del trabajo, a la circulación como placer" (Debord y otros, 1977, p. 113)-; la creación de situaciones para dar usos distintos al espacio urbano; la identificación de psicogeografías que relacionen lo afectivo con los espacios y recorridos por la ciudad; y la crítica general a la llamada "sociedad del espectáculo" en términos de su política alienante del uso del tiempo libre. El rechazo al orden espectacular en la sociedad y ciudad moderna es denunciado especialmente por Guy Debord en La sociedad del espectáculo: "El espectáculo es el mapa de este nuevo mundo, un mapa que cubre íntegramente su territorio" (2000, p. 49), el de "la organización espectacular de la no-vida" (Debord, 2000, p. 116). En cada uno de sus aspectos, la ciudad parece dominada por la demanda del espectáculo de repartir de manera excluyente las funciones de ver o actuar, ser público o actor. Gracias a esta división, los mecanismos del capitalismo vuelven a capturar el tiempo -y la vida, convertida en no vida- del trabajador, primero en el espacio de producción y ahora en su tiempo libre. El fruto del trabajo proletario se convierte en mercancía a través del espectáculo, más veces deseada que obtenida: "El espectáculo es el momento en el cual la mercancía alcanza la ocupación total de la vida social" (Debord, 2000, p. 55). Es exhibida en el espacio público, en las vitrinas y vallas publicitarias, como también en la vitrina doméstica de la televisión. También el espacio y transporte público es organizado en función de una mayor circulación en el menor tiempo posible, entre los lugares de producción y los del consumo de la mercancía y el espectáculo: "el espectáculo de los automóviles exige una circulación perfecta que destruya las viejas ciudades, mientras que el espectáculo de la propia ciudad necesita barrios-museos" (Debord, 2000, p. 68). La antigua ciudad, con sus calles y plazas marcadas por las distintas experiencias de hacer territorio, son dispuestas ahora para la industria del turismo. Frente a esta distribución espectacular del espacio urbano que exigen la productividad capitalista, el Movimiento Internacional Situacionista reacciona proponiendo la deriva en lugar de la circulación; la psicogeografía en lugar del espacio funcional; la creación de situaciones lúdicas en lugar del plan regulador del urbanismo moderno; una ocupación lúdica, estética, existencial del espacio público.

Otras reflexiones y propuestas también intentan crear territorios que escapen al orden espectacular, integrando nuevamente el ver con el actuar en una sola expresión, como en el carnaval popular. El arte se propone tener un papel principal en la sensibilización del público, promoviendo su participación activa y oponiéndose al control capitalista que terminó convirtiendo la obra de arte en mercancía y el museo en espectáculo. En la segunda mitad del siglo XX aparecen propuestas como el situacionismo, las acciones, los performances, la intervención y circulación en medios masivos, o la estética relacionista, que devuelven al arte su función de construcción colectiva y social. Negri, en una de sus cartas sobre multitudo, encuentra en éstas una decidida voluntad de desmitificar el misterio del arte y la práctica profesionalizante que promovieron su mercado y espectacularización. Debe retornarse a sus raíces populares, con sus:

(...) efectos catárticos [donde] la exhibición del arte como manufactura daba lugar al esclarecimiento de su naturaleza no misteriosa, y por tanto a la liberación de las mistificaciones estéticas o mercantiles que sobre él se operaba. (Negri, 2000, p. 42)

De manera distinta Jacques Ranciere denuncia en El espectador emancipado la "repartición de lo sensible" (2010). Primero evidencia el supuesto de la ignorancia del espectador 
frente a los modos de producción del espectáculo, que conllevan las propuestas modernas del situacionismo o las del teatro de Antonin Artaud o Bertold Brecht. Éstas, al definir al público por su no actuar, suponen que el espectador frente al espectáculo "ignora el proceso de producción de esa apariencia o la realidad que ella encubre" (Rancière, 2010, p. 10). Así, el teatro épico de Brecht proponía:

(...) arrancarlo del embrutecimiento del espectador fascinado por la apariencia y ganado por la empatía que lo obliga a identificarse con los personajes de la escena. (Rancière, 2010, p. 11)

Mientras el teatro de la crueldad de Artaud exigía que fuera:

(...) sustraído a la posición de observador (...) ser despojado de este ilusorio dominio, arrastrado al círculo mágico de la acción teatral en el que intercambiará el privilegio del observador racional por aquél que consiste en estar en posesión de sus plenas energías vitales. (Rancière, 2010, p. 12)

Para Rancière, en estas dos propuestas que buscaban la participación del espectador, convirtiendo la sala de teatro en una asamblea política o en lugar de purificación a partir de la crueldad, existía aún una "partición de lo sensible" que supone la división en términos de opuestos entre mirar y saber, apariencia y realidad, actividad y pasividad. Es necesario entonces preguntarse:

¿Por qué identificar mirada y pasividad, si no es por el presupuesto de que mirar quiere decir complacerse en la imagen y en la apariencia, ignorando la verdad que está detrás de la imagen y la realidad fuera del teatro? (Rancière, 2010, p. 18)

Para Rancière la emancipación del espectador "comienza cuando se cuestiona de nuevo la oposición entre mirar y actuar [...] y se comprende que mirar es también acción" (2010, p. 19). No hay una mirada neutra, ya que a través de ésta el espectador hace un ejercicio por el que selecciona, compara, comprende e interpreta el espectáculo en relación con su realidad. Inevitablemente se da una traducción, se toma del espectáculo para hacer su propia narración, aquí empieza su participación. No habría que emancipar ni purificar a nadie, cada cual y cada comunidad lo hace en relación con sus necesidades y capacidades: "una comunidad emancipada es una comunidad de narradores y traductores" (Rancière, 2010, p. 27).

Esta idea, con su positividad frente a la potencia política del espectador, vuelve a hacer pensar la forma en que a través de su propia autogestión y formas de apropiación, una comunidad se empodera y construye territorios, ahora mediante el uso de los medios. Los medios no son sólo la maquinaria de producción, distribución y consumo de la mercancía hecha espectáculo, también son y han sido la herramienta con que las comunidades construyen lo propio, lo común, y lo "popular urbano". Éste es para Martín-Barbero el trabajo en las "mediaciones" (1998). Quizá las tecnologías de comunicación por medio de Internet y en soporte digital vuelvan a hacer pensar en una apropiación de los medios de producción de imágenes, en "mediaciones" que permitan responder económica, ágil y rápidamente a las necesidades y deseos de distintas comunidades en este nuevo espacio de lo público: el ciberespacio. 


\section{CIBERESPACIO Y TERRITORIO}

A finales del siglo XX la digitalización de todo tipo de información y la distribución de estos contenidos por medio de Internet se consideran las más nuevas tecnologías. En 1995 se publican dos textos influyentes sobre la transformación que estas implican: Ser digital (1995) del profesor de MIT Nicholas Negroponte y ¿Qué es lo virtual? (1999) del filósofo francés Pierre Levy. Ambos anuncian una nueva época para el hombre contemporáneo; más que nuevos inventos, se trata de nuevas formas de ser y estar en el mundo. El posible desarrollo de lo digital y lo virtual ya había sido imaginado como un nuevo territorio en la ciencia ficción: el ciberespacio, explorado en las narrativas de William Gibson desde los años ochenta, pensamientos y desarrollos tecnológicos que superaban las posibilidades de la televisión. La red de la televisión es para Negroponte "una jerarquía de distribución con una fuente (de donde viene la señal) y muchos sumideros (hacia donde van las señales)" (1995, p. 183); y para Levy "no cesa de mostrar poderosos y víctimas a masas de individuos aislados e impotentes" (1999, p. 115). El mecanismo de la televisión que mantiene a un público masivo dividido en "aislados e impotentes" grupos, recibiendo contenidos emitidos desde una sola "fuente" -tan eficaces para la política y economía capitalista-, es transformado por Internet: de un sistema que irradia información (y, hasta cierto punto, control) del centro hacia las periferias, a una compleja red en la que el centro puede estar en cualquier nodo y el flujo informático ir en cualquier dirección.

Negroponte se centra en la potencia mecánica que produce la digitalización de la información y el conocimiento, su fácil acceso, lectura, distribución y operación para la máquina binaria. Su definición del "ser digital" es una ontología de la "máquina inteligente." A Levy le interesa más la potencia maquínica de la multitud, mediada por la ágil comunicabilidad de la gran máquina en red al servicio del colectivo de sus usuarios. Lo "virtual" para él es aquello que potencia las multitudes, actualizado en la comunidad humana que habita el "ciberespacio", un plano de conjunción existencial y vital, de lo digital y lo físico. La tecnología que contribuía más a la fragmentación social del régimen del espectáculo parecía ser superada por una nueva forma de producir y acceder a la información y de comunicarse entre los seres humanos en el mundo, pero puede sospecharse de esta ilusión en la misma manera en que se intentaba definir como "superautopista de la información" por Negroponte. Para Levy, la idea de "autopista electrónica degrada a cosa apropiable lo que antes era un objeto circulante" (1999, p. 115). El término evidencia una utilización de la circulación, distribución, mercado y consumo de la información dentro de las leyes del mercado mundial del capitalismo. Levy propone más bien pensar la red como "una manera inédita de crear una sociedad inteligentemente [...]. Una manera original de constituir colectivos inteligentes" (1999, p. 115), prefiriendo entonces hablar "telépolis". "Superautopista de la información" o "telépolis", dos metáforas distintas para un mismo invento. La primera que podría repudiar aquellos situacionistas que se manifestaban contra la idea de circulación del urbanismo moderno y más asimilable a los espacios amplios, ágiles y regulados de los supermercados; la segunda remite más al ágora de la polis griega, lugar por excelencia de todo tipo de intercambios administrados por sus usuarios. Un debate de intereses se da en torno a su funcionamiento: en la definición como "circulación" en un espacio marcado por "autopistas" previas, o la idea, un tanto aventurera, que implica la "navegación" en un territorio aún por cartografiar. 
Quizá también la resistencia a ser cartografiado es la que diferencia entre un "espacio estriado" y un "espacio liso". Deleuze y Guattari encuentran una "diferencia de naturaleza" entre el espacio estriado del sedentario y el liso del nómada en la forma como en éstos se pueden resistir al "aparato de captura" (2006, pp. 483-506). Esta diferencia puede aplicarse también al cibersespacio: uno que busca registrar todo uso, circulación y producción, a través de las legislaciones de copyright, y otro en el que se resiste a partir de "máquinas de guerra" del tipo copyleft o las licencias creative commons. Negroponte presenta su metáfora de "superautopista de la información", como una estructura cuya posibilidad va más allá de ofrecer un veloz encuentro del tesoro buscado en el juego infantil, "más que un simple atajo hacia todos los libros de la Biblioteca del Congreso de los Estados Unidos, es crear una estructura social global, del todo nueva" (1995, p. 185). Mientras, Levy, más que una potente implementación tecnológica y social, ve en lo virtual una transformación humana en tanto colectividad: "el nervio del ciberespacio no es el consumo de informaciones o de servicios interactivos, sino la participación en un proceso social de la inteligencia colectiva" (2007, p. 167). Negroponte piensa más la relación entre el hombre y la máquina, incluso desde la potencialidad de ésta como máquina inteligente: "mi sueño sobre una interfaz, es que las computadoras sean cada vez más similares a las personas" (1995, p. 107). Levy supone la mediación entre individuos y comunidad por medio de la máquina, como una creciente "inteligencia colectiva", no como metáfora sino como:

(...) un "concepto coherente": un "sujeto colectivo (...), una inteligencia en la que el sujeto sea a la vez múltiple, heterogéneo, distribuido y cooperativo/competitivo, y este constantemente comprometido en un proceso auto-organizador y auto-poiético. (1999, p. 92)

La multitud aparece nuevamente reivindicada por el uso creativo, crítico y colectivo de estas nuevas tecnologías, siglos después de que la modernidad política la hubiese eclipsado tras las nociones de pueblo y masa. En su libro Multitud, Hardt y Negri imaginan como un enjambre aquel concepto con que Spinoza definía la multitud en el siglo XVII, el Ingenium multitudinis:

No existe un uno que toma una decisión en el cerebro, sino más bien un enjambre, una multitud que actúa de común acuerdo (...) El propio cuerpo es una multitud organizada en el plano de la inmanencia. (2004, p. 383)

No habría posibilidad de un progreso humano, de su asombrosa producción e innovación, sino a través de una construcción colectiva, su genialidad reside en la multitud, en el ingenium multitudinis. Acercan ahora este concepto a las actuales posibilidades, ya que no sólo refleja la colectividad del cuerpo-cerebro, sino que es sobre todo una noción del trabajo colectivo humano, como el que puede construirse en Internet: "acudimos al símil de una red distribuida, a Internet, como imagen y modelo para una primera explicación de la multitud" (Hardt y Negri, 2004 , p. 16). Levy tampoco duda de que "una sociedad totalmente inteligente siempre será más eficaz que una sociedad dirigida inteligentemente" (1999, p. 108). Sin embargo, para él no es exacta la comparación de la "inteligencia colectiva" con un enjambre de insectos, abejas, hormigas o termitas: 
La inteligencia colectiva piensa en nosotros [además de que], nosotros podemos disfrutar individualmente de la inteligencia colectiva, que aumenta o modifica nuestra propia inteligencia. (Levy, 1999, p. 100)

En su libro Imperio, Hardt y Negri ven cómo estas tecnologías pueden ser apropiadas para la construcción del sujeto colectivo de la multitud que:

Se traslada por senderos infinitos y adquiere forma corporal mediante la reapropiación del tiempo y la hibridación de los nuevos sistemas maquinales (...) Ahora se trata de plantear dentro de estas dimensiones el problema del devenir-sujeto de la multitud. (2005, p. 427)

Es un "nosotros" como manifiesto colectivo cohesionado ahora por las redes sociales virtuales, tal como deben ser para Levi:

La virtualización alcanza incluso a las formas de estar juntos, a formación del "nosotros": comunidades virtuales, empresas virtuales, democracias virtuales, etc. (1999, p. 13)

Como lo piensan Hardt y Negri, es una comunidad empoderada de estos medios y mediante los que puede constituir su propia forma de autogobernarse y ser soberana, siendo: "por fin capaz de dirigirse a sí misma" (2004, p. 387). La "multitud" es la que ahora realiza su propia asamblea, foros que no obligan a ser consensos, espacios de participación colectiva que no anulan las creencias y expresiones de cada uno, sino que permiten "el derecho a la desobediencia y el derecho a la diferencia, fundamentales en la multitud" (Hardt y Negri, 2004, p. 386): un cuerpo organizado en un plano de inmanencia, en el que no hay un cerebro sino un cuerpo en devenir.

Pero sólo articulando el ciberespacio y el espacio público puede construirse el lugar donde sucede lo real, es decir lo práctico y lo político, donde las comunidades puedan realizar las ideas discutidas y concertadas en la red. Lo virtual sólo permite lo real, el ciberespacio se concreta y se realiza como acción y acontecimiento en el espacio físico de la calle y de la plaza, en el que se da cita una comunidad. Para Levy:

Lo virtual viene a ser el conjunto problemático, el nudo de tendencias o de fuerzas que acompaña a una situación, un acontecimiento, un objeto a cualquier entidad y que reclama un proceso de resolución: la actualización. (1999, p. 18)

En el Informe al Consejo de Europa en 1997, el mismo Levy se pregunta cómo articular la virtualidad del ciberespacio con la territorialidad de la ciudad (2007). Nuevamente entran en juego el concepto propuesto por Deleuze y Guattari de territorio, pues se trata de un movimiento evidente de "desterritorialización" hacia el ciberespacio propiamente virtual y otro de "reterritorialización" donde lo virtual toma lugar como un hecho o acontecimiento (2006). La actualización es también convertir en formas visibles, audibles y habitables un sistema de signos y códigos, como las tradiciones orales, la escritura, las grabaciones audiovisuales, las redes digitales, para que constituyan "ritmos, velocidades o cualidades diferentes" (Levy, 1999, p. 23). Levy propone al Consejo de Europa: "la articulación de dos espacios cualitativamente muy diferentes, el del territorio y el de la inteligencia colectiva", sin que esto consista en "elimi- 
nar las formas territoriales para reemplazarlas por un estilo de funcionamiento ciberespacial" (2007, p. 168). Para él la verdadera democracia electrónica consiste en:

Animar tanto como es posible -gracias a las posibilidades de comunicación interactiva y colectiva ofrecidas por el ciberespacio- la expresión y la elaboración de los problemas de la ciudad por los ciudadanos mismos, la autoorganización de las comunidades locales, la participación de las deliberaciones de los grupos directamente concernidos por las decisiones, la transparencia de las políticas públicas y su evaluación por los ciudadanos. (Levy, 2007, p. 158)

Es claro que la posibilidad de construir territorios políticamente eficaces a través de redes sociales virtuales no consiste en:

(...) abandonar el territorio para perderse en el "mundo virtual", (...) sino más bien a utilizar el mundo virtual para vivir aún mejor en el territorio, para convertirse en ciudadano enteramente. (Levy, 2007, p. 170)

En Colombia, en los últimos días de agosto de 2013, se han visto en Canal Capital y en YouTube algunas imágenes del paro agrario en Boyacá, que no fueron mostradas en los medios de información de mayor circulación -los periódicos El Tiempo y El espectador, y los canales de televisión RCN y Caracol. Desde una vivienda campesina en Tibasosa una mujer graba con el celular desde su casa cómo se acerca un escuadrón del ESMAD hasta romper los vidrios de las ventanas. Ella los encuadra y les avisa que los está grabando en video: "ahí estamos grabando para que se vean en yutu lo lindo que quedan (...), mire, posen para que se vean en yutu ahorita"; a lo que responde algún policía: "no les tenemos miedo"; y la mujer continua: "nosotros tampoco les tenemos miedo, abusivos". En este caso, la producción de imágenes propias, usando sus dispositivos como el celular y subiéndolos rápidamente a YouTube, dio poder a las comunidades campesinas para mostrar las evidencias del abuso de la policía. Las imágenes aumentaron su divulgación a través de la edición que de ellas se hizo en Canal Capital denunciando el maltrato y exigiendo respeto para los campesinos. El ciberespacio daba voz y visibilidad a la población más invisibilizada del mayor conflicto territorial nacional: la tenencia de la tierra en el campo. Más allá del consumo habitual de los medios, la comunidad se apropió de éstos usándolos para acceder al mundo virtual desde un territorio que quiere construirse de la mejor manera para vivir. Como esta campesina, muchos se unieron a una multitud que ejerció su ciudadanía como individuos y colectivo a la vez. Se trata de un movimiento de "desterritorialización" -donde el manejo del medio sorprende junto al acento de la campesina-, que vuelve a la "reterritorialización" que supone su lucha por lograr un mundo mejor para los suyos.

Ya se habían visto en Colombia usos de los medios digitales y las redes virtuales en la conformación de alianzas estratégicas, entre el ciberespacio y la construcción de territorios en el espacio público urbano. En noviembre de 2008 la Minga de Resistencia Social Indígena llegó a Bogotá y la Plaza de Bolívar después de marchar durante un mes más de 400 kilómetros, desde sus territorios originarios en la cordillera central del departamento del Cauca. Esta marcha fue seguida desde YouTube, donde se anunciaba, se animaba desde las ciudades y se denunciaban los atropellos sufridos. Los videos en YouTube entusiasmaron a las comunidades urbanas para pintar grafitis y alistarse a recibir con cantos la marcha desde la capital: " ¡Viva la 
vida! ¡Fuera los paracos!." En las calles y la plaza, la música, la danza, las lenguas, las banderas y los bastones de mandos indígenas constituyeron un territorio de resistencia, en el que se afirmaba una forma de ser "nosotros", en pleno espacio representativo del poder oficial colombiano, donde han sido tradicionalmente ignoradas estas comunidades. Nuevamente el uso de medios digitales y el espacio virtual dieron como resultado el desplazamiento de un territorio marginal hacia el centro del poder nacional, haciéndose posible a través del acompañamiento virtual de la marcha indígena una de sus formas tradicionales de hacer territorio: el caminarlo.

Un antiejemplo desafortunado del intento de hacer territorio valiéndose exclusivamente de las redes sociales virtuales, para convocar discutir y compartir un "nosotros" fue el de la campaña del Partido Verde y su candidato Antanas Mockus para las elecciones presidenciales de 2010-2014. A ésta se sumaron con gran entusiasmo una multitud de jóvenes cibernautas aportando su ingenio y creatividad en el diseño, realización y circulación de imágenes y mensajes. En las redes sociales virtuales la participación fue multitudinaria, impulsando una creciente "Ola Verde" que prometía un drástico cambio moral, ético y ecológico, en medio de la tradicional corrupción de la política colombiana. Pero la Ola Verde que se suponía iba a vencer con creces a las otras campañas presidenciales fue derrotada ampliamente en las mesas de votación. La multitudinaria participación ciudadana sólo tuvo lugar en el ciberespacio, pues nunca llegaron los prometidos electores al espacio público, a las plazas y calles a votar. No hubo una "multitud" viva en el "espacio público", parecía más bien una inmensa cantidad de jóvenes -quien sabe si alcanzaban la mayoría de edad-que se quedó expectante y desilusionada ante las pantallas de sus computadores, viendo cómo su creatividad y su "héroe" -como el de un simulacro virtual- era derrotado en la plaza pública. La "Ola Verde" nunca tuvo lugar más allá del espacio virtual, nunca se "actualizó," no se hizo real. Ésta es la situación de la que Levy prevenía: no se trata de "abandonar el territorio para perderse en el mundo virtual" (2007, p. 170), pues la vida se realiza finalmente en el espacio físico. El ciberespacio puede contribuir a hacer el territorio, pero no lo reemplaza.

En octubre de 2011 una serie de manifestaciones tuvieron lugar articulando eficazmente el espacio público virtual con el espació público físico. Desde hace años la protesta estudiantil en Colombia venía caracterizándose por un reiterativo y agotado ritual de cantos, pancartas, pasamontañas y gestos de airada violencia como explosiones e incendios animados casi siempre por infiltrados de la extrema derecha e izquierda. Sin embargo, las marchas estudiantiles contra las reformas propuestas por la administración Santos a la Ley 30 de 1992 o ley de educación superior, al ser motivadas por una auténtica preocupación de esta comunidad sobre sus posibilidades de acceder a la mejor educación pública universitaria, mostraron una renovada expresión del desacuerdo y la protesta. En el debate sobre la ley se organizó una Mesa Ampliada Nacional Estudiantil que discutió y contrapropuso al gobierno sus reformas, a la vez que se programaron una serie de marchas de estudiantes que sorprendieron en su renovada creatividad: en performance, cantos y estribillos, máscaras y comparsas, pancartas y consignas, que debían mostrar nuevos problemas, nuevas soluciones y nuevas formas. Además, con distintas herramientas de la red-páginas, Facebook o YouTube- se divulgó la ley, sus críticas y propuestas, como también las imágenes de las protestas, que fueron generando otra forma de participar en ellas, incluso con personalidades públicas que se sumaron a la causa. Aunque la policía y los escuadrones de ESMAD estuvieron en todas, los cantos y acciones de los estudiantes no se dirigieron a éstos como sus enemigos sino como sus aliados: las pancartas decían "Ni ley 30, ni reforma, queremos universidad pública para 
todos"; los coros cantaban "policía, tu hijo es estudiante" y corrían hacia los uniformados a abrazarlos. Esta inesperada acción desarmó a los policías que decían haber sido preparados para agredir o responder violentamente, y no para recibir abrazos. Los medios oficiales que tradicionalmente enfatizan en una minoría de provocaciones que generan revueltas violentas, para desacreditar las protestas, esta vez no pudieron reducirla a "actos vandálicos" sino a la "abrazatón", como el mismo RCN resaltó. El ex presidente Francisco Santos se quejó en su VideoBlog de la debilidad del nuevo presidente frente a los estudiantes -a quien "le están midiendo el aceite"-, proponiendo el uso de armas no letales -como descargas eléctricas-, para que la policía pueda disolver las marchas. Esta intervención en video fue intervenida y comentada con sátiras, ediciones y grafismos, que volvieron a subirse a YouTube mostrando la caricatura de este político, Ilamándolo "Fachito Santos". El uso del ciberespacio fue así aprovechado para informar, convocar y discutir las acciones de protesta y propuesta que los estudiantes hacían en el espacio público, y para desacreditar y burlarse de las facilistas y fascistas salidas de algunos políticos.

\section{CONCLUSIÓN: TERRITORIO Y CIBERESPACIO EN LATINOAMÉRICA}

Durante un siglo de realización de eventos en el espacio público urbano, puede observarse en éstos muchas conformaciones y propósitos distintos, revelando diferentes relaciones dadas entre un poder que insiste en establecerse y legitimarse, y las diferentes formas de agruparse de una colectividad. La forma en que se da esta relación se diferencia en: unos espectáculos programados desde los poderes oficiales y dirigidos a un público o pueblo que consideran pasivo en la recepción de sus formas y contenidos; otros que surgen desde las clases populares y se establecen como una multitud festiva y que pueden obtener el beneplácito de los gobiernos, a los que les sirve para liberar tensiones sociales; y otros que acontecen circunstancialmente desde los sectores subalternos y marginales, como un estallido de las presiones sociales, con o sin una organización política clara.

Los primeros poseen un orden espectacular en el que se reparte tanto el espacio público como los roles sociales entre un público y el espectáculo. Obedecen en buena medida a las estrategias de un proyecto estatal oficialista que busca promover, construir y hacer perdurar una imagen de nación en la población, que en el mejor de los casos se quiere que responda a la denominación de "pueblo". Estos eventos, generalmente conmemorativos, reiteran la historia fundacional y el valor de los héroes que legitiman al poder presente, una versión de un conjunto de hechos que se tejen en un solo relato; esta historia que no debe ser olvidada, aunque tampoco debe ser actualizada. Pertenecen estos eventos al mismo programa de los museos nacionales o los programas escolares de cívica e historia patria que García Canclini caracteriza (1990). Se instituyen en una serie de rituales civiles o religiosos como desfiles militares y procesiones religiosas, encargados de recordar el "mito nacional" en espacios que son hitos históricos. Desde sus comienzos, el cine en Colombia participó en el registro y divulgación de estos espectáculos. Gracias a medios como la radio y la televisión, éstos pueden ser transmitidos y emitidos en grandes pantallas instaladas en espacios público, pero sobretodo en las pantallas domésticas asegurándose de alcanzar todo tipo de públicos en la más pequeña e influyente de las células sociales: la familia. Si el cine fue a su vez un espectáculo público y masivo, la recepción de la televisión se da sobretodo al interior de los hogares. También estos eventos hoy se ponen en escena en los lugares más recónditos, 
transmitiéndolos por televisión como una forma de recorrer los límites del territorio nacional y darle un mayor alcance y fuerza a la recepción de esta versión de la historia. Aquí se trata de la constitución, divulgación y permanencia de un territorio nacional.

En el caso de la fiesta o el carnaval popular, el espacio no se segmentaba para dirigir la mirada del público hacia un foco donde sucede un espectáculo, porque este último ya no tiene lugar. Se trata de una participación y creación colectiva, motivada por unos patrones que rápidamente son intervenidos, variados y transgredidos, dándole cabida a la improvisación espontanea. Si en un primer momento hay comparsas y desfiles, la multitud empieza a participar en ellos hasta disolver las fronteras entre espectáculo y público. Aunque cumple con una periodicidad y programación, en su interior pueden suceder muchas situaciones y eventos, pues precisamente es el lugar de la licencia donde cada uno puede ser el que quiera y dejar de cumplir su rol social establecido. Más que un colectivo homogéneo, que una sola voz en la que se pueda identificar un pueblo, hay multitudes que se mezclan y mutan constantemente, sólo respetando el lapso temporal que permite la subversión y transgresión de las reglas sociales. En un principio las cámaras de los registros se perdieron en medio de las multitudes arrastradas por la fuerza dionisiaca de esta forma de construir territorio. La danza, la música, las máscaras y disfraces, y el consumo de sustancias desinhibitorias o alucinógenas logran contagiar el lenguaje cinematográfico de los primeros registros de carnavales urbanos. Sin embargo, estos eventos también son capturados por los poderes que los colonizan económicamente mediante la industria del turismo e ideológicamente como propagandas nacionalistas. Esto se observa claramente en su nueva conformación como espectáculos, con inmensas graderías a lado y lado de las calles en las que suceden los más tradicionales carnavales, como el de Barranquilla o el de Blancos y Negros en Colombia. El contraste entre los primeros registros cinematográficos de los carnavales de estudiantes en Bogotá y las transmisiones para televisión de carnavales como el de Río de Janeiro, muestra claramente cómo el carnaval popular se convierte en espectáculo, la participación colectiva en turismo, las multitudes en masas, y una cámara entrometida en la comunidad en una dispuesta para una gran producción televisiva de espectáculos masivos, como un mundial de futbol. La construcción de un territorio con un alto grado de creación y participación colectiva se transforma en espectáculo turístico administrado por empresas mixtas que conjugan la participación estatal y la de grandes corporaciones privadas, mas no la de los intereses públicos: lo que queda de popular es un contenido convertido en mercancía ofrecida a las masas.

Finalmente parece ser que sólo en ciertas marchas de disidencia y protesta, las de aquellos que reclaman sus derechos y una participación en los procesos sociales, es donde en los últimos años permanecen formas de hacer territorio más relacionadas con la vida misma. No son eventos conmemorativos ni espectáculos turísticos, sino acontecimientos sociales convertidos en especies de carnavales populares, por su forma de participación y creación colectiva en la que termina por celebrarse la aspiración a una renovación buscada, una celebración de la vida misma en formas de explosión de alegría, furor o ira. En ellas reaparecen, últimamente, reinventándose cantos y estribillos, máscaras y disfraces, coreografías de marchas y danzas, performances, e intervenciones al mismo espacio público, expresando una diversa y renovada manera de hacer territorio. Son las masas urbanas en explosión en las que las multitudes se hacen presentes con sus diferencias y disidencias, pero dentro de un conjunto aglutinado por algún propósito común: la marcha de distintas comunidades indígenas expresando sus nece- 
sidades en medio de una sociedad que las ignora; la manifestación de un inmenso conjunto de estudiantes de diferentes sectores sociales, que alegan su derecho a hacer parte de las decisiones sobre la educación pública; la protesta reivindicatoria del diverso sector campesino maltratado por los tratados de libre comercio, etc. Estas masas expresándose en su diversidad dan cuenta de las multitudes que fueron eclipsadas por la imagen de pueblo homogéneo que impuso la modernidad. La celebración de la vida, con toda su espontaneidad y necesidad, esta allí, en una colectividad que busca su autotransformación, un acontecimiento. Imposible no pensar en la fiesta y la revolución que estuvieron juntas en el acontecimiento que ha quedado como un mito histórico signado en la fecha de mayo de 1968: "Llegamos aquí, pues, a ese momento de alegría y de creación absoluta", dice Tony Negri en su carta a Manfredo (2000, p 49). La creación absoluta es el producto del trabajo colectivo: la ciudad, el lenguaje, la historia, el hacer territorio, y más allá de la figura del autor, impuesta en la modernidad: el arte. También a Manfredo le escribe: “El arte es, pues, uno de los productos del trabajo colectivo. Es de esta sustancia suya de la que hablamos aquí" (Negri, 2000, p 43). Tony Negri en su carta a Silvano explica cómo el acontecimiento requiere del arte para concretarse en construcción colectiva:

Hay acaso una tensión más increíble que ésta: la de un relato que rechaza el pasado para trasladarse al futuro, que lo pone todo en tensión hacia un nuevo acontecimiento. Acontecimiento que no puede ser más revolucionario. Y cuando se dice revolucionario, atravesando la noción de lo bello, se dice una acción de masa tan profunda que implica un efecto transformador sobre la estructura del ser. Sobre la constitución de la existencia, a través de las vicisitudes de una liberación, a través de la recomposición de la libertad y de lo abstracto, de la vida y del proyecto. Arte como multitudo: con la revolución, más allá del mercado, para determinar excedencia de ser. (2000, pp. 70-71)

Ya no se vale de una representación espectacular de un pasado convertido en leyenda para exponerlo como relato ejemplarizante, ni de una licencia dentro de un lapso espacio temporal que permite realizar el sueño de ser quien no se puede ser en la vida real, liberando así las tensiones acumuladas en medio del sometimiento y el aplazamiento de los sueños de vida. Aquí no se asiste a una representación ni se representa un sueño vital, sino que se expresa la urgente necesidad de transformar el presente en un futuro deseado, sin más aplazamiento. Este acontecimiento no promete un futuro ideal sino que exige su realización en la vida misma, es la renovación en sí misma, la liberación de las fuerzas opresoras, la revolución puesta al día.

La forma contemporánea en que estos acontecimientos se realizan no puede dejar de lado el trabajo colectivo que también se da en las redes virtuales, en las que se citan las multitudes, proponen y discuten sus ideas, y finalmente se hacen presente en conjunto expresando cada una su forma de participar, imaginar y crear un sueño colectivo. Los medios ya no pueden ser vistos sólo como un lugar de consumo, ya que cada vez más ciertas comunidades se apropian de éstos para expresarse como sujetos colectivos. Para Martín-Barbero, específicamente en América Latina:

(...) la irrupción de esas tecnologías se inscribe en un viejo proceso de esquizofrenia entre modernización y posibilidades reales de apropiación social y cultural de aquello que nos moderniza. $(1998$, p. 251) 
Se trata de nuevas formas de participar en lo público, desde escenarios donde cada vez más se diluyen las fronteras entre lo privado y lo público. Para García Canclini (1990), en el nuevo contexto de urbanización y transformación de la circulación y recepción de contenidos informativos y simbólicos, que pasan de los medios masivos a Internet, se modifican las relaciones entre público y privado. La manifestación de colectividades en el espacio público alcanzan nuevas posibilidades gracias a la posibilidad de encontrarse y lograr preacuerdos en el espacio virtual. El poder de éstas crece:

(...) si actúan en las redes masivas: no sólo la presencia urbana de una manifestación de cien o doscientos mil personas, sino -más aún- su capacidad de interferir el funcionamiento habitual de una ciudad y encontrar eco, por eso mismo, en los medios electrónicos de información. (García Canclini, 1990, p. 266)

Sin embargo, esta "cultura urbana" puede ser reestructurada al "ceder el protagonismo del espacio público a las tecnologías electrónicas" (García Canclini, 1990, 269). La circulación de ideas, textos e imágenes en Internet convoca a una inmensa multitud comunicada y creando entre sí, para finalmente actualizar toda aquella virtualidad en el espacio público. En este último momento es cuando los cantos, slogan, imágenes, performances propuestos que circularon en el espacio virtual se condensan en un acontecimiento en el que la energía de cada uno se proyecta en el conjunto y la del conjunto alimenta la de cada uno, en un gran celebración de la vida, una fiesta. La alegría vital, del inofensivo carnaval de estudiantes censurado a final de los años treinta del siglo XX reapareció transformada en amenazante fuerza colectiva en las marchas estudiantiles de 2011. Si en primera instancia parece banal hablar de las luchas sociales, las protestas, marchas y revueltas como carnaval o fiesta es porque no se ha observado en la forma esencial del carnaval una fuerza transformadora que ya no pide permiso, que no es más una representación para un público y que no da espera a una fecha de conmemoración de un pasado, sino que se manifiesta como la vida misma celebrando lo nuevo y su puesta en acción inmediata. En medio de la alegría colectiva que provee la marcha colectiva de un "nosotros" puede comprenderse como el lugar por excelencia de la realización de la vida misma en una forma de hacer territorio en que cada uno contribuye con su propia invención y creación. Se trata de que la multitud no haga de la fiesta una revuelta, sino de la marcha y de la revolución una fiesta que celebre la vida, y que ésta pueda durar tanto como la vida.

\section{NOTAS}

1 "Cine-ojo" o Kino-glatz, es para Vertov la perfecta simbiosis entre el hombre y la máquina en el caso del ojo y el cine.

2 Kinoki es el nombre dado por Vertov a sus camarógrafos, a quienes practican el "cine-ojo". 


\section{REFERENCIAS}

¿Qué es la democracia? Álvarez, Carlos dir. Colombia. 1971.

“¡No al Proyecto de la Reforma de la Ley 30! ¡Universidad Pública!." http://www.youtube.com/ watch? $v=10 a C C 5 L V V B o$

"Abrazatón, marcha estudiantil en Bogotá". Noticiero RCN. http://www.youtube.com/ watch?v=aagb9qauA_o

"Fachito Santos". http://www.youtube.com/watch?v=mKv57JyYTpo

“Fragmentos Palacio de Justicia 6 y 7 de noviembre 1985." http://mww.youtube.com/watch?v=UJyxvOw_ bdw

“La Minga en Bogotá: de la U. N. a la Plaza de Bolívar." http://www.youtube.com/watch?v=blF_bzb5Z-4

“Le miden el aceite al presidente.".http://www.youtube.com/watch?v=ypSbMONX-Sw

"Por el respeto". Canal Capital. http://www.youtube.com/watch?v=D5dOAYZmyy8

Acosta, Luisa Fernanda. Celebración del poder e Información Oficial. La Producción cinematográfica informativa y comercial de los Acevedo (1940-1960), 2005. http:// historiacritica.uniandes.edu.co/view.php/308/view.php. (Acceso: 1 de agosto de 2013).

Agarrando pueblo. Mayolo, Carlos y Ospina, Luís dirs. Colombia. 1978.

Álvarez, Carlos. Sobre cine colombiano y latinoamericano. Bogotá: Universidad Nacional de Colombia, 1989.

Bajtín, Mijaíl. La cultura popular en la edad media y el renacimiento. El contexto de Francois Rabelais. Madrid: Alianza Editorial, 2002.

Benjamin, Walter. Discursos interrumpidos I. Buenos Aires: Tauros S.A. Ediciones, 1989.

Canetti, Elias. Masa y poder. Barcelona: Random Hause Mondadori, S. A., 2006.

Colombia 70. Álvarez, Carlos dir. Colombia. 1970.

Confesión a Laura. Orozco, Jaime dir. Colombia. 1991.

Debord, Guy y otros. La creación abierta y sus enemigos. Madrid: Ediciones de la Piqueta, 1977.

Debord, Guy. La sociedad del espectáculo. Valencia: Pre-textos, 2000.

Deleuze, Gilles y Guattari, Félix. Mil mesetas, capitalismo y esquizofrenia. Valencia: Ediciones Pretextos, 2006.

Deleuze, Gilles. La imagen-tiempo. Estudios sobre cine 2. Barcelona: Ediciones Paidós, 1987.

Dubois, Philippe. El acto fotográfico. De la representación a la recepción. Barcelona: Ediciones Paidós Ibérica S. A., 1986.

El Hombre de la cámara. Vertov, Dziga dir. URSS. 1929.

Escobar, Ticio. El mito del arte y el mito del pueblo. Cuestiones sobre arte popular. Santiago de Chile: Ediciones Metales pesados, 2008.

Gaitán sí. Valencia Gaitán, María dir. Colombia. 1998.

García Canclini, Néstor. Culturas híbridas. Estrategias para entrar y salir de la modernidad. México: Editorial Grigalbo S. A., 1990.

Getino, Octavio y Solanas, Fernando. "Hacia un tercer cine". En Hojas de cine. Testimonios y documentos del Nuevo Cine Latinoamericano Vol. 1. México: Fundación Mexicana de Cineastas, 1988.

Gubern, Román. La mirada opulenta, exploración de la iconosfera contemporánea. Barcelona: Editorial Gustavo Gili, s. A., 1987.

Hardt, Michael y Negri, Toni. Imperio. Barcelona: Ediciones Paidós Ibérica S. A., 2005. 
Hardt, Michael y Negri, Toni. Multitud, guerra y democracia en la era del Imperio. Barcelona:

Random House Mondadori S. A., 2004.

La Gente de la Universal. Aljure, Felipe dir. Colombia. 1994.

La Historia del baúl rosado. Gómez, Libia Estela dir. Colombia. 2005.

La Hora de los hornos. Getino, Octavio y Solanas, Fernando dirs. Argentina. 1968.

La Primera noche. Restrepo, Luís Alberto dir. Colombia. 2003.

La sociedad del semáforo. Mendoza, Rubén dir. Colombia. 2010.

La Sombra del caminante. Guerra, Ciro dir. Colombia. 2004.

Lévy, Pierre. ¿Qué es lo virtual? Barcelona: Ediciones Paidós Ibérica S. A., 1999.

Lévy, Pierre. Cibercultura. Informe al consejo de Europa. Barcelona: Anthropos Editorial, 2007.

Martín-Barbero, Jesús. De los medios a las mediaciones. Bogotá: Convenio Andrés Bello, 1998.

Mora, Cira Inés y Carrillo, Adriana María. "Acevedo e Hijos". Cuadernos de Cine Colombiano, Bogotá, núm. 2. (2002).

Negri, Toni. Arte y multitudo. Ocho cartas. Madrid: Editorial Trotta S. A., 2000.

Negroponte, Nicholas. Ser digital. (Being Digital, MIT, 1995). Buenos Aires: Editorial Atlántida, 1995.

Nichols, Bill. La representación de la realidad. Barcelona: Ediciones Paidós S. A., 1991.

Nieto, Jorge y Rojas, Diego. Tiempos del Olympia. Bogotá: Fundación Patrimonio Fílmico Colombiano, 1992.

Pasado Meridiano. Arzuaga, José María dir. Colombia. 1966.

Perder es cuestión de método. Cabrera, Sergio dir. Colombia. 2004.

Pérgolis, Juan Carlos. Bogotá fragmentada. Cultura y espacio urbano a fines del siglo XX. Bogotá: TM Editores, 1998.

Pérgolis, Juan Carlos. Estación Plaza de Bolívar. Bogotá: Instituto Distrital de Cultura y Turismo, 2000.

Raíces de piedra. Arzuaga, José María dir. Colombia. 1961.

Rancière, Jacques. El espectador emancipado. España: Eliago Ediciones, 2010.

Rapsodia en Bogotá. Arzuaga, José María dir. Colombia. 1964.

Roa. Baiz, Andy dir. Colombia. 2013.

Romero, José Luis. Latinoamérica: las ciudades y las ideas. México D.C.: Siglo XXI Editores S. A., 1976.

Salcedo Silva, Hernando. Crónicas del cine colombiano: 1897-1950. Bogotá: Carlos Valencia Editores, 1981.

Satanás. Baiz, Andy dir. Colombia. 2007.

Serrat, Joan Manuel. Fiesta. http://www.musica.com/letras.asp?letra=1004354 (Acceso: 13 de junio de 2013).

Soplo de vida. Ospina, Luís dir. Colombia. 1999.

Suárez, Juana. Cinembargo Colombia. Ensayos críticos sobre cine y cultura. Bogotá: Editorial Universidad del Valle, 2009.

Vertov, Dziga. Memorias de un cineasta Bolchevique. Barcelona: Editorial Labor S. A., 1974.

Virno, Paolo. Gramática de la multitud, para un análisis de las formas de vida contemporánea. Buenos Aires: Ediciones Colihve, 2003.

Zuluaga, Pedro Adrián. ¡Acción! Cine en Colombia. Bogotá: Ministerio de Cultura de Colombia, 2007. 


\section{Cómo citar este artículo:}

Castro Durán, Mauricio. "Territorios urbanos a partir de las imágenes mediáticas: desfiles, carnavales, manifestaciones y revueltas en Bogotá. Cuadernos de Música, Artes Visuales y Artes Escénicas, 9 (1), 95-138, 2014, http://dx.doi.org/10.11144/ Javeriana.MAVAE9-1.tupm 